\title{
Fibroblast-to-myofibroblast transition in bronchial asthma
}

\author{
Marta Michalik $^{1}$ - Katarzyna Wójcik-Pszczoła ${ }^{1,2} \cdot$ Milena Paw $^{1} \cdot$ Dawid Wnuk $^{1} \cdot$ Paulina Koczurkiewicz ${ }^{1,2}$. \\ Marek Sanak ${ }^{3} \cdot$ Elżbieta Pękala $^{2} \cdot$ Zbigniew Madeja $^{1}$
}

Received: 4 March 2018 / Revised: 26 July 2018 / Accepted: 6 August 2018 / Published online: 12 August 2018

(c) The Author(s) 2018

\begin{abstract}
Bronchial asthma is a chronic inflammatory disease in which bronchial wall remodelling plays a significant role. This phenomenon is related to enhanced proliferation of airway smooth muscle cells, elevated extracellular matrix protein secretion and an increased number of myofibroblasts. Phenotypic fibroblast-to-myofibroblast transition represents one of the primary mechanisms by which myofibroblasts arise in fibrotic lung tissue. Fibroblast-to-myofibroblast transition requires a combination of several types of factors, the most important of which are divided into humoural and mechanical factors, as well as certain extracellular matrix proteins. Despite intensive research on the nature of this process, its underlying mechanisms during bronchial airway wall remodelling in asthma are not yet fully clarified. This review focuses on what is known about the nature of fibroblast-to-myofibroblast transition in asthma. We aim to consider possible mechanisms and conditions that may play an important role in fibroblast-to-myofibroblast transition but have not yet been discussed in this context. Recent studies have shown that some inherent and previously undescribed features of fibroblasts can also play a significant role in fibroblast-to-myofibroblast transition. Differences observed between asthmatic and non-asthmatic bronchial fibroblasts (e.g., response to transforming growth factor $\beta$, cell shape, elasticity, and protein expression profile) may have a crucial influence on this phenomenon. An accurate understanding and recognition of all factors affecting fibroblast-to-myofibroblast transition might provide an opportunity to discover efficient methods of counteracting this phenomenon.
\end{abstract}

Keywords Fibrosis $\cdot$ Lungs $\cdot$ TGF- $\beta$-signalling $\cdot$ Pro-fibrotic agents $\cdot$ Mechanical forces

Marta Michalik and Katarzyna Wójcik-Pszczoła contributed equally.

Marta Michalik

marta.michalik@uj.edu.pl

$\triangle$ Katarzyna Wójcik-Pszczoła

katarzynaanna.wojcik@uj.edu.pl

1 Department of Cell Biology, Faculty of Biochemistry, Biophysics and Biotechnology, Jagiellonian University, Gronostajowa 7, 30-387 Kraków, Poland

2 Department of Pharmaceutical Biochemistry, Faculty of Pharmacy, Jagiellonian University Medical College, Medyczna 9, 30-688 Kraków, Poland

3 Division of Molecular Biology and Clinical Genetics, Department of Medicine, Jagiellonian University Medical College, Skawińska 8, 31-066 Kraków, Poland

\section{Introduction}

Bronchial asthma is one of the most common chronic diseases in the world. It affects over $10 \%$ of the human population, and its prevalence is still rising. Bronchial asthma is a clinically heterogeneous, chronic inflammatory disorder of the airways characterized by their hyperresponsiveness to environmental stimuli and by airflow limitation. The regulatory mechanisms and consequences of inflammation in asthma form a complicated network of reciprocal influences, including a sequence of events through which structural and infiltrating cells and their signalling molecules are involved in the irreversible rebuilding of the bronchial wall (called remodelling) [1, 2]. Airway remodelling is defined as a sequence of chronic structural changes that lead to thickening of the airway wall, epithelial damage, subepithelial fibrosis, increased deposition of extracellular matrix (ECM), smooth muscle hypertrophy, and increased vascularity [3-6]. Severe asthma, as defined by the clinical presentation, is most strongly associated with remodelling. However, 
inflammatory cell subtypes in asthma are also relevant to the thickening of the bronchial wall. Eosinophilic inflammation of the airways was found to correlate with the loss of lung function due to a decline in the FEV1/FVC ratio [7]. However, in a recent study, transgenic expression of interleukin- 8 in bronchial epithelium mimicked a severe asthma phenotype in mice and induced the neutrophilic phenotype and progressive remodelling of the airways [8].

Despite extensive research, several important questions concerning the pathogenesis of asthma remain unanswered. It is not clear whether airway remodelling is a normal response to chronic inflammation or, alternatively, whether the remodelling process itself may be a primary event in asthma development independent of inflammation [6]. Some evidence shows that airway inflammation is not the only cause of remodelling. First, changes in the bronchial wall can occur in early childhood, not necessarily subsequent to, but rather before inflammation [9-11]. Second, drugs specifically targeting inflammatory pathways that are commonly used in asthma treatment have had limited or no success in suppressing bronchial wall remodelling [12-14]. Moreover, many recent population and epidemiological studies have indicated that hereditary factors are very important in the development of asthma and in bronchial wall remodelling [15-20]. It is well documented that the lungs of patients with asthma are characterized by airway narrowing and increased thickness of the airway wall (thickening of muscle bundles and subepithelial fibrosis), which correlate with the severity of bronchial asthma [21, 22]. Subepithelial fibrosis occurs in the airway mucosa, which contains mainly fibroblasts, myofibroblasts, inflammatory cells, vessels and ECM proteins $[3,5]$. The thickening of muscle bundles results from hyperplasia and hypertrophy of airway smooth muscle cells (ASMC) and their distinct hyper-reactive ('primed') phenotype, which are characterized by increased release of proinflammatory and immunomodulatory factors [6]. The key role of ASMC in remodelling has been intensively investigated and fairly well clarified [6, 23-29]. The thickening of the asthmatic (AS) subepithelial layer is due to exaggerated deposition of ECM proteins (primarily collagen I, III, and $\mathrm{V}$ and non-collagenous proteins, including elastin, tenascin, fibronectin and laminin), which are predominantly produced by activated ASMC, fibroblasts and myofibroblasts [30-34]. To complete the picture of events occurring in AS bronchial walls, fibroblasts, myofibroblasts and their interactions should also be considered. These remarkable cells appear to be crucial for the changes leading to narrowing of the airway lumen. The contribution of myofibroblasts to the progression of bronchial wall remodelling in asthma is indisputable, but the role of fibroblasts in the subepithelial layer in myofibroblast transition, although frequently described, remains ambiguous. In this review, we aim to assemble the current knowledge on components and processes that may lead to myofibroblast formation, especially as a result of fibroblastto-myofibroblast transition (FMT) in bronchial asthma.

\section{Myofibroblasts in the bronchial wall}

Myofibroblasts are mesenchymal cells that, due to their phenotype, are often described as a cross between fibroblasts and smooth muscle cells. Myofibroblasts are able to synthesize ECM proteins (as are fibroblasts) and the myocytespecific isoform $\alpha$-smooth muscle actin ( $\alpha$-SMA), which is visible in cells as stress fibres. These features enable myofibroblasts to induce a contractile force. It is generally accepted that myofibroblasts (including bronchial myofibroblasts from AS individuals), in addition to their expression of $\alpha$-SMA, express transgelin (SM-22- $\alpha$ ), smooth muscle myosin, osteopontin, and calponin- 1 and are interconnected via gap junctions, highlighting their similarities with smooth muscle cells. As mesenchymal cells, myofibroblasts express vimentin and fibroblast surface protein (FSP) [35-41]. The contractile apparatus of myofibroblasts is composed of $\alpha$-SMA-enriched bundles of microfilaments terminated with focal adhesions (FAs) positive for integrins $(\alpha 1, \alpha 3$, $\alpha 4, \alpha 5, \alpha \mathrm{V}, \beta 1$ ), vinculin, paxillin, talin, and tensin [42-45]. It was shown that compared to fibroblasts, human bronchial myofibroblasts have a larger mean surface area and reduced extension of cell shape (extension is a measure of how much the shape differs from a circle, taking a value of zero if the shape is circular and increasing without limit when the shape becomes less circular) [46]. Human bronchial fibroblasts (HBFs) are generally smaller and less elongated than mature myofibroblasts [46-48].

Bronchial myofibroblasts are not only contractile but also metabolically active. AS myofibroblasts display increased expression and secretion of ECM components, such as collagens I, III, and V, fibronectin [49, 50], tenascin [51] and proteoglycans (lumican, versican biglycan and decorin) $[50,52,53]$. Enhanced collagen production by fibroblasts and myofibroblasts leads to greater thickness of the lamina reticularis in bronchi of AS patients (between 4 and $12 \mu \mathrm{m}$, in comparison with 2-6 $\mu \mathrm{m}$ in non-asthmatic (NA) subjects) [49, 54-56]. Chu et al. suggest that although increased collagen deposition in the subepithelial basement membrane is a characteristic of asthma, it may not explain the differences in severity of asthma [57]. It is known that myofibroblasts are also a source of matrix metalloproteinases (MMPs) and their inhibitors (tissue inhibitors of metalloproteinase, TIMP) [33, $58,59]$. In bronchoalveolar lavage fluid (BALF), sputum, and airway biopsies from AS subjects, increased MMP-9 and TIMP-1 expressions were demonstrated [60-62]. However, compared to control subjects, AS subjects have a significantly lower MMP-9 to TIMP-1 ratio, which correlates with the degree of airway obstruction. Weitoft and co-workers 
demonstrated that in both controlled and uncontrolled asthma, the MMP-9/TIMP-3 ratio is decreased [50]. Many reports have also shown that myofibroblasts are an abundant source of inflammatory mediators, cytokines, chemokines, and growth factors, such as granulocyte-macrophage colony-stimulating factor (GM-CSF), interleukins (IL-1, IL-6, IL-8), stem cell factor (SCF), transforming growth factor type $\beta$ (TGF- $\beta$ ), and vascular endothelial growth factor (VEGF) [63-66]. Thus, myofibroblast-derived factors may act not only on themselves but also on other airway and immune cells, such as smooth muscle cells, by promoting cell migration, hyperplasia and hypertrophy $[67,68]$.

Several sources of myofibroblasts have been identified thus far. Myofibroblasts may arise as a result of both epithelial-to-mesenchymal transition (EMT) [69-72] and endothelial-to-mesenchymal transition (EndoMT) [73]. Fibrocytes and mesenchymal stem cells circulating in the blood and originating from bone marrow may also be a source of myofibroblasts [74-81]. Fibrocytes are an important source of myofibroblasts in chronic severe asthma [82]. Myofibroblasts can also be derived from differentiated pericytes [83, 84] or smooth muscle cells [40]. However, the most common source of myofibroblasts is the population of fibroblasts residing in the connective tissue of bronchi, as under the influence of various stimuli, fibroblasts can change their phenotype to that of myofibroblasts.

\section{FMT}

FMT is a phenomenon that occurs in the human body under both physiological and pathological circumstances. An increase in myofibroblast formation in the connective tissue as well as disturbances in apoptosis is related to impaired wound healing and chronic inflammation. Thus, abnormal myofibroblast formation is often described in the pathogenesis of fibrotic diseases. Enhanced formation of myofibroblasts has also been reported in subepithelial remodelling in asthma [85, 86].

The primary mechanism of FMT has been discovered and described in wound healing [87]. Numerous in vitro studies have suggested that the FMT process requires two stages. In the initial phase, fibroblasts develop a transitional phenotype known as proto-myofibroblasts, which are then converted into fully differentiated (mature) myofibroblasts $[42,88]$. Fibroblast-to-proto-myofibroblast transition is facilitated by mechanical tension within the wound and is accompanied by ED-A fibronectin [89] and platelet-derived growth factor (PDGF) secretion. PDGF is able to induce the formation of stress fibres and increase the motility of cells [90]. The formed proto-myofibroblasts express both $\beta$ - and $\gamma$-actin isoforms (incorporated into stress fibres) and $\mathrm{N}$-cadherin, which exert less adhesion force than OB-cadherin but facilitate the increased motility of proto-myofibroblasts [91]. Distinguishing between fibroblasts and proto-myofibroblasts is very difficult in vitro because most of the fibroblasts in culture exhibit a proto-myofibroblast phenotype [88]. A prolonged state of high stress and the presence of FMTstimulating cytokines, growth factors and ECM proteins cause proto-myofibroblasts to initiate synthesis of $\alpha$-SMA and gradually form $\alpha$-SMA-containing stress fibres. Fully differentiated myofibroblasts express OB-cadherin, possess mature FAs (containing de novo expression of focal adhesion kinase (FAK) and tensin), and exhibit less motility, a reduced proliferation rate and enhanced contractility [42, 64, 91].

In asthma and other fibrotic lung disorders, FMT proceeds in a similar manner, but its effect on the bronchi microenvironment seems to be different. Typically, myofibroblasts enter the apoptosis pathway after fulfilling their function. Some in vitro studies have suggested that normal lung myofibroblasts can differentiate back into fibroblasts $[92,93]$. In asthma, myofibroblasts seem to remain within the tissue and actively participate in bronchial wall remodelling by inducing a contractile force on the surrounding cells and ECM as well as by secreting growth factors and ECM components [94].

\section{Stimuli affecting FMT in asthma}

Previous studies on the nature of FMT have led to the identification of various factors involved in the induction of this phenomenon in asthma. The humoural agents primarily include growth factors, cytokines and chemokines. The second group of FMT-triggering agents are mechanical factors, among which intercellular interactions and the interaction of cells with different substrates and ECM proteins should be distinguished. Due to the complicated pathogenesis of asthma, many FMT stimuli may interact with one another, thereby leading to further induction of FMT. The most important and best-described FMT-triggering factors in asthma are summarized in Table 1.

\section{Humoural factors}

According to the current literature, the role of growth factors in triggering FMT is unquestionable and fundamental. Among all the identified pro-fibrotic factors, the best known is TGF- $\beta$. Three homologous isoforms of TGF- $\beta$ have been identified (TGF- $\beta_{1}$, TGF- $\beta_{2}$ and TGF- $\beta_{3}$ ). TGF- $\beta$ is secreted into the extracellular space by both bronchial structural cells (epithelial cells, fibroblasts, endothelial cells, vascular cells and ASMC) and inflammatory cells infiltrating the bronchial wall (eosinophils, macrophages) [95-98]. Literature data indicate that all TGF- $\beta$ isoforms are secreted in the AS 
Table 1 Overview of factors affecting FMT in asthma

\begin{tabular}{|c|c|c|c|}
\hline \multicolumn{4}{|l|}{ Humoural factors } \\
\hline Growth factors & Interleukins & Chemokines & Others \\
\hline $\begin{array}{l}\text { TGF- } \beta(\beta 1,-\beta 2)[95,97,98, \\
118-128] \\
\text { CTGF }[126-128,135] \\
\text { PDGF }[90,136,137] \\
\text { NGF }[139-141]\end{array}$ & $\begin{array}{l}\text { IL-4 }[146-151,154,155,157] \\
\text { IL-13 [146-154, 156-159] } \\
\text { IL-5 [150] } \\
\text { IL-11 [160,161] } \\
\text { IL-17 [162-166] } \\
\text { IL-25 [167-170] } \\
\text { IL-33 [171, 172] } \\
\text { Oncostatin M [173] } \\
\text { TNF- } \alpha[118]\end{array}$ & $\begin{array}{l}\text { Osteopontin [184] } \\
\text { Eotaxin-1 [183] } \\
\text { Eotaxin-2 }[182,185] \\
\text { Eotaxin-3 }[182,185] \\
\text { Periostin }[154,187,198]\end{array}$ & $\begin{array}{l}\text { Bradykinin [204] } \\
\text { Cysteinyl leukotrienes (LTD4) [202, 203] } \\
\text { Fizz1 [199-201] } \\
\text { Endothelin-1 [205, 206] }\end{array}$ \\
\hline \multicolumn{3}{|l|}{ Mechanical factors } & ECM proteins \\
\hline \multicolumn{3}{|l|}{$\begin{array}{l}\text { Mechanical forces/stress [91, } 2 \\
\text { Substrate stiffness }[212,217] \\
\text { Cell-cell adhesions [44, 223] } \\
\text { Epithelial cells with an asthmat }\end{array}$} & $\begin{array}{l}\text { Fibronectin domain (ED-A) [226] } \\
\text { Tenascin [229] }\end{array}$ \\
\hline
\end{tabular}

lung, but among them, the $\beta_{1}$ and $\beta_{2}$ isoforms seem to be the most significant [99-103]. Increased levels of TGF- $\beta$ in the bronchi $[95,104]$ and BALF of AS subjects have been described $[105,106]$. The existence of a relationship between the amount of TGF- $\beta$ present in the respiratory tract and the severity of asthma has also been suggested [106, 107]. Nevertheless, several studies investigating the expression of TGF- $\beta_{1}$ in asthma have shown conflicting results. It has been demonstrated in human bronchial biopsy specimens that there are no differences in the immunohistochemical staining of TGF- $\beta_{1}$ between AS and control subjects [56, $108,109]$. However, TGF- $\beta$ has been confirmed to play an important role in most cellular biological processes leading to airway remodelling in asthma. TGF- $\beta$ affects different cell types and exhibits pleiotropic and immunomodulatory functions [95, 106, 110-115]. Depending on the chemical and mechanical conditions, TGF- $\beta$ may have pro- or antiapoptotic effects on epithelial cells [116] and can induce EMT in airway epithelial cells from AS subjects [117]. It is well documented that TGF- $\beta$ is able to trigger FMT in AS subjects both in vitro [95, 97, 98, 118, 119] and in vivo [120-122]. It was also shown that in AS subjects, TGF- $\beta$ can indirectly contribute to fibrosis by triggering the production of other fibrosis mediators, such as interleukin-6 (IL-6) [123]. TGF- $\beta$ can also induce or enhance the secretion of fibroblast growth factor-2 (FGF-2), connective tissue growth factor (CTGF) and VEGF from fibroblasts, myofibroblasts or airway smooth muscle [124-128].

CTGF (also known as CCN2) is another important growth factor that participates in fibrotic processes in bronchial asthma. CTGF is also involved in the course of chronic inflammatory diseases [129] and is overexpressed in the lung tissue and plasma of AS subjects [130]. This growth factor in bronchi is mainly produced by fibroblasts, epithelial cells, endothelial cells and ASMC. The role of CTGF in bronchial wall remodelling, similar to that of FMT, mainly involves mediating many of the effects of TGF- $\beta$ [126-128, 131]. For example, it was demonstrated that TGF- $\beta$-induced CTGF release can enhance fibronectin, collagen I and VEGF production by ASMC [132-134] as well as induce FMT [126-128, 135].

There is no doubt that in addition to the well-coordinated activities of TGF- $\beta$ and CTGF, other growth factors directly or indirectly participate in FMT induction in asthma. PDGF, for example, increases the migration and phenotypical shifts of lung fibroblasts from AS patients [90] and has been shown to induce procollagen I expression in lung fibroblasts derived from patients with severe asthma [136] and increase the lung fibroblast proliferation rate in AS subjects [137]. In turn, nerve growth factor (NGF), the level of which is elevated in AS airways, [138] is able to induce fibroblast activation, fibronectin-induced fibroblast migration, and $\alpha$-SMA and matrix contraction in pulmonary fibroblasts [139-141]. It also seems that basic fibroblast growth factor (bFGF), PDGF and insulin growth factor 1 (IGF-1) can positively regulate lung fibroblast proliferation in asthma $[118,142]$.

Other substances that are of great importance in triggering FMT are pro-inflammatory cytokines and chemokines (Table 1). Inflammation clearly plays a key role in asthma pathogenesis [1, 143-145]. An elevated influx of immune cells is associated with increased vascular permeability, and a release of cytokines and chemokines has been observed in AS airways during disease exacerbation. Presumably, interleukins, including IL-4 and IL-13, are strongly associated with inflammatory reactions in asthma. The participation of interleukins in FMT is also quite well understood. IL-4 and IL-13 may directly act on lung fibroblasts and induce myofibroblastic transition through the downregulation of 
cyclooxygenase (COX) gene expression and reduction of prostaglandin $\mathrm{E}_{2}$ production [146]. Moreover, IL-4 and IL-13 can induce FMT through the c-Jun NH2-terminal kinase-dependent pathway [147]. In addition, both interleukins are important players in the induction of the myofibroblast phenotype [148-159]. How other interleukins affect the induction of FMT in asthma has not been explained, but several in vitro and in vivo studies have suggested that many interleukins may increase the potential of FMT in a TGF- $\beta$-dependent or TGF- $\beta$-independent manner. For example, cytokines that can indirectly and directly induce FMT are IL-5 [150], IL-11 [160, 161], IL-17 [162], IL-17A [163-166], IL-25 [167-170], IL-33 [171, 172], tumour necrosis factor type $\alpha$ (TNF- $\alpha$ ) [118], interleukin-6 (IL-6) superfamily members, and oncostatin M (OSM) [173]. All of the above cytokines have also been reported to be overexpressed in asthma [150, 174-180].

In the group of chemokines, special interest within the context of FMT induction should be paid to eotaxins (eotaxin-1, eotaxin-2 and eotaxin-3) [181-184], osteopontin (OPN) [39, 185, 186], and periostin [154, 187-190]. First, OPN is upregulated in asthma and associated with bronchial remodelling in humans. In addition, increased subepithelial expression of OPN correlates with disease severity $[39,186]$. In mice, OPN has been demonstrated to induce the transition of lung fibroblasts into myofibroblasts [185]. Another set of chemokines, eotaxins, can selectively modulate lung and bronchial fibroblast activity by increasing fibroblast proliferation and by regulating MMP-2 activity, collagen synthesis, and cell migration [182, 183]. Recently, there has been particular interest in periostin as a pro-fibrotic factor in asthma [154, 188-191]. This biomarker of eosinophilia and type 2 inflammation in asthma is produced mainly by epithelial cells, fibroblasts, eosinophils, and fibrocytes [103, 154, 192-196]. The participation of periostin in the promotion of fibroblast transition into myofibroblasts and the induction of fibroblast migration has been described [187, 197]. It is also possible that periostin, as a co-factor of TGF$\beta$, promotes ECM production and FMT [154, 187, 198].

In the group of humoural factors that induce FMT, attention should also be paid to unclassified factors such as Fizz1 [199-201], cysteinyl leukotrienes [202, 203], bradykinin [204] and endothelin-1 (ET-1) [205, 206]. All of these factors can also act directly on myofibroblast formation.

\section{Mechanical factors}

The second group of FMT-inducing factors (Table 1) includes mechanical factors. It is well known that the state of mechanical tension and changes in the tissue microenvironment are crucial for FMT efficiency. Physical alterations involved in the formation of myofibroblasts in a variety of tissues, including lung tissues, have been investigated for more than 10 years $[40,45,88,207]$. A number of studies both in vitro (with fibroblasts in 2D culture on different surfaces or in 3D collagen gels with different stiffness) and in vivo (with animal models) have shown that mechanical stress is one of the most potent factors controlling fibroblast phenotypical shifts and cell fate [208-212]. Hinz and coworkers demonstrated that proto-myofibroblasts may arise only on substrates exhibiting an elastic modulus of at least $3000 \mathrm{~Pa}$ and that sometimes, even stiffer culture substrates with a Young's modulus of $20 \mathrm{kPa}$ or higher are required to permit further myofibroblast transition [212]. It was also shown that the stiffness threshold for myofibroblast differentiation in vitro during wound healing is approximately $25-50 \mathrm{kPa}$ [207]. As measured by atomic force microscopy, fibrotic lung tissue is up to 30 times stiffer than normal lung tissue (the Young's modulus ranges between $20-100$ and 1-5 $\mathrm{kPa}$, respectively) [213-216].

It is worth emphasizing that there are few studies on the direct impact of "mechanical forces" on the lung or bronchial FMT in asthma. The exception is the study by Shi and colleagues, which showed that TGF- $\beta_{1}$-induced bronchial FMT as well as cell stiffness and contractility was enhanced by increasing substrate stiffness in culture [217]. In contrast, many reports have described the effect of mechanical forces on airway remodelling in asthma [218, 219]. Numerous studies have shown an increase in ECM protein and proteoglycan content (versican, decorin, collagen I and III), MMP-2 and MMP-9 synthesis, and IL-6 and IL-8 production in AS fibroblasts under mechanical stress [218-222].

A study of bronchial and transbronchial biopsies from AS subjects revealed that patients with uncontrolled asthma have significantly increased numbers of myofibroblasts (in central airways and alveolar parenchyma) and different compositions of ECM proteins compared to patients with controlled asthma [50]. As described by Weitoft and others, the features and resulting differences in elasticity may be partly responsible for the mechanical properties of lung tissue in subjects with uncontrolled asthma. One explanation for the increased rigidity and reduced flexibility within bronchi in asthma may be the increased deposition of ECM proteins. It is well known that a local increase in matrix stiffness after injury causes an increase in the number of myofibroblasts (or FMT), which in turn results in increased secretion of ECM proteins (mainly collagens), finally causing an increase in stiffness of the ECM [40, 212]. The outcome of this feedback loop determines fibroblast morphology and actin cytoskeleton architecture and, consequently, affects the FMT process, wherein $\alpha$-SMA incorporation into stress fibres, increases in the size of FAs and increases in cell contractility are observed [212]. It has been previously shown that in contrast to fibroblasts from NA bronchi, fibroblasts from AS bronchi cultured in vitro in serum-free medium, thus ensuring a lack of cell-cell interactions, are 
characterized by numerous, extremely thick and prominent actin cytoskeleton and relatively large FAs. These features directly contribute to the higher stiffness of fibroblasts from AS subjects than that of fibroblasts from NA subjects [44]. Other findings have shown that the initial absence or induced loss of cell-cell adhesions in AS fibroblasts is crucial for the completion of FMT [223]. In addition, Reeves et al. reported that the interaction between fibroblasts and epithelial cells could also be essential for the changed predisposition of ECM production in fibroblasts. Increased ECM and $\alpha$-SMA synthesis observed in fibroblasts co-cultured with epithelial cells from bronchi of AS subjects may be the consequence of their response to the diseased epithelial cell phenotype $[34,224]$. The above-mentioned interactions play an important role in inducing FMT. Although there are few reports indicating the direct involvement of mechanical factors in asthma-related FMT, their participation in this process is undeniable.

\section{ECM proteins that trigger FMT in asthma}

A particularly important factor in the ECM protein group for the promotion of FMT is the fibronectin splice variant ectodomain A (ED-A-FN). The level of this protein was found to be increased in asthma and other pulmonary disorders [37, 48, 225]. Lung fibroblasts from OVA-treated mice lacking ED-A-FN exhibited reduced proliferation, migration, $\alpha$-SMA expression, and collagen deposition as well as impaired TGF- $\beta_{1}$ and IL-13 release [226]. As it is known that ED-A-FN binds TGF- $\beta$ in the ECM and that it can directly interact with cells via integrins, further explanation of its unusual role in triggering FMT in asthma is not necessary. Although there is no clear evidence of the direct effect of other ECM proteins on FMT, their possible indirect influence on myofibroblast development cannot be ignored. Thus, special attention should be paid to tenascin. This myofibroblast marker is overexpressed in asthma [51,
227, 228], and its deficiency in animal models of asthma was shown to attenuate airway inflammation and, in particular, eosinophilia, IL-5 and IL-13 levels in BALF [229]. Recently, fibulin-1, a new marker of bronchial asthma, was identified [230, 231]. This secreted glycoprotein stabilizes other ECM proteins. Considering the undeniable influence of mechanical stress on FMT, increased stability of the ECM may increase fibroblast susceptibility to FMT. Another potential indirect effect of ECM on the regulation of myofibroblast formation is related to the ability of ECM proteins to bind selective growth factors. These growth factors, which may be produced in increased quantities by AS airways, are subject to a variety of interactions with ECM proteins. The direct relationship of TGF- $\beta$ binding to ECM in asthma has not yet been described, but given that the regulation of TGF- $\beta$ may depend on its binding to ECM proteins [94, 232], we suggest that such an interaction could also be important in asthma-related FMT.

\section{Fibroblast features}

It is generally accepted that the above-listed and described factors are crucial for FMT in asthma. However, some recently published results of in vitro studies have suggested that inherent fibroblast features can also play a significant role in this process. Michalik et al. showed that bronchial fibroblasts derived from AS patients demonstrate enhanced TGF- $\beta_{1}$-induced potential to differentiate into myofibroblasts compared to their NA counterparts [46, 223], which may be attributed to the inherent features of these cells (Fig. 1).

The different properties of AS and NA HBFs that are associated with their predilection to FMT have recently been documented. Several reports have revealed significant differences in cell morphology (mainly in cell shape) between bronchial fibroblasts derived from AS and NA donors cultured under the same standard conditions [44,

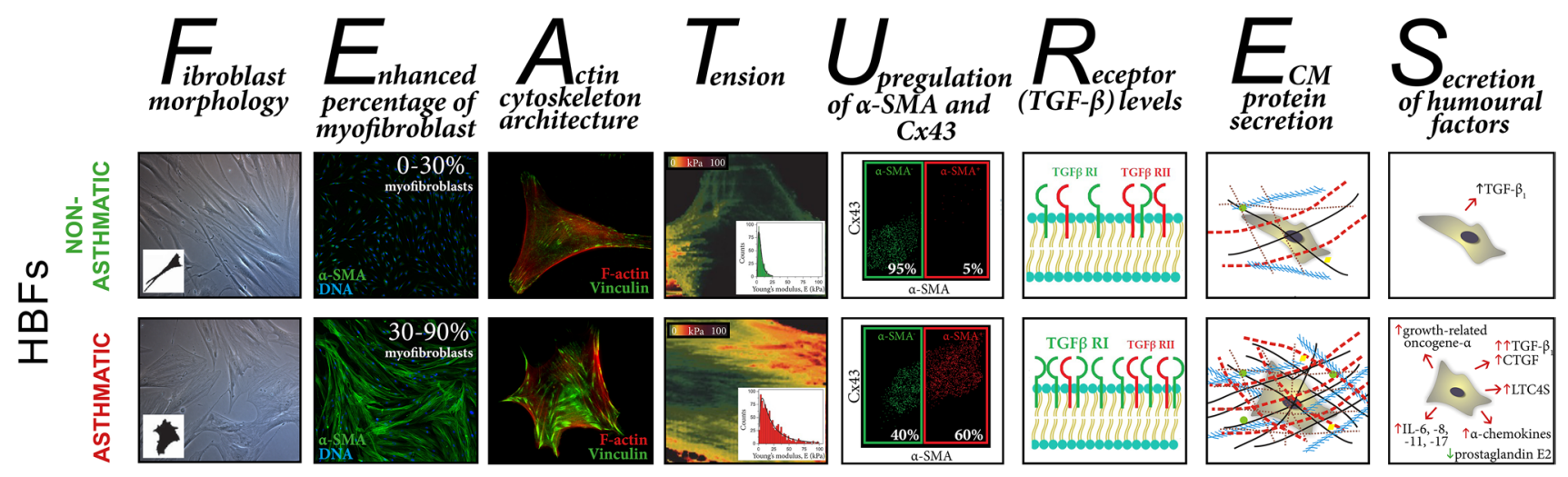

Fig. 1 Differences in the inherent features of human bronchial fibroblasts derived from asthmatic and non-asthmatic donors that affect their potential to undergo TGF- $\beta$-induced FMT 
46] (Fig. 1-fibroblast morphology). In addition, Kotaru et al. [233] noticed substantial differences in cell size within populations of fibroblasts isolated from proximal and distal parts of AS lungs, which correlated with their predilection to FMT. Moreover, it was shown that TGF- $\beta_{1^{-}}$or TGF- $\beta_{2^{-}}$ induced FMT is accompanied by striking cell shape changes and that this phenomenon was improved in HBFs derived from AS subjects [46]. These observations correlated with an enhanced number of cells with de novo expression of $\alpha$-SMA and with the incorporation $\alpha$-SMA into highly contractile microfilament bundles in AS HBF populations in contrast to NA counterparts (Fig. 1-enhanced percentage of myofibroblasts) [36, 46, 204, 223, 234, 235]. Moreover, AS human lung fibroblasts (HLFs) expressed higher levels of SM22 (a protein that establishes the smooth muscle lineage of cells) than NA fibroblasts [235].

Recently, Sarna et al. used a combination of cytofluorimetric and nanomechanical analyses to demonstrate significant differences in actin cytoskeleton architecture in HBFs derived from AS patients and those derived from NA donors [44]. In contrast to NA HBFs, AS HBFs formed thick and aligned ventral stress fibres accompanied by enlarged FAs (Fig. 1-actin cytoskeleton architecture). These differences in cytoskeleton architecture between AS and NA fibroblasts correlate with the high elastic modulus and isometric tension of unstimulated ( $\alpha$-SMA-negative) AS HBFs (Fig. 1tension) and their increased predilection to TGF- $\beta$-induced FMT [44].

Different behaviours of NA and AS HBFs are also observed after external stimulation. Many reports indicate that the pro-fibrotic potential of HBFs derived from AS subjects is multiplied in response to humoural and/or mechanical factors. After stimulation, AS HBFs exhibited different expression patterns of some proteins compared to NA HBFs. The most important and notable differences are amplified levels of $\alpha$-SMA and connexin (Cx) 43 (protein involved in the intercellular transfer of small metabolites and ions via hexameric channels termed gap junctions) [236, 237] in response to TGF- $\beta$ administration in AS HBFs compared to NA HBFs (Fig. 1-upregulation of $\alpha$-SMA and Cx43) $[46,223,234,238]$. It was shown that increased levels of Cx43 in AS HBFs correlated with their FMT potential [234]. Humoural stimulation of HBFs from AS donors induced an increased level of bradykinin B2 receptor [204], leukotriene C4 synthase and CysLT1 receptors [239], PAI-1 [235], and MRTF-A [235] but also a decreased level of prostaglandin E2 [240].

Differences in the level of TGF- $\beta$ receptors were also found between AS and NA HBFs and may have an impact on FMT potential (Fig. 1 -receptors TGF- $\beta$ level). The results of previous studies clearly indicate that although the level of TGF- $\beta$ RII in AS and NA cell populations is comparable [238], significantly increased levels of TGF- $\beta$ RI in
HBFs from AS subjects compared to their counterparts from healthy donors were observed [203].

Additionally, AS HBFs (through their higher tension) affect the expression of ECM components and enhance their secretion into the surrounding microenvironment (Fig. 1ECM protein secretion). Significant differences in the expression of collagens, especially type I [158, 217, 235], proteoglycans [241], versican [221, 222], low-molecularweight hyaluronan [242], fibronectin [235, 243], decorin [221] and tenascin C [229, 244], have been reported. Moreover, although procollagens I and III synthesis is similar in both groups of cells [137], the balance between (pro)collagen synthesis and degradation in HBFs from AS patients is unknown $[245,246]$. This phenomenon is also associated with the TIMP/MMP ratio, which is unbalanced in AS HBFs [245]. These characteristics lead to the increased rearrangement and deposition of ECM components, which support the phenotypic transformation of HBFs [49, 119, 158, 217], as described earlier.

Additionally, in response to the administration of humoural factors, HBFs from AS donors secrete significantly increased levels of CTGF, IL-6, IL-8, IL-11, IL-17, $\alpha$-chemokines and growth-related oncogene- $\alpha$ compared to their NA counterparts (Fig. 1-secretion) [106, 127, 163, $222,247]$. Similarly, the increased secretion of an active form of TGF- $\beta_{1}$ is observed in both unstimulated HBFs from AS donors and HBFs under pro-inflammatory conditions [106, 158, 203]. In response to mechanical stress, HBFs from AS donors exhibit significant upregulation of IL-6, IL-8, MMP-2, MMP-9, collagen I and III expression $[158,217,219,222,244]$. Enhanced expression and secretion of these proteins may further auto-stimulate HBFs from AS subjects to undergo phenotypic transformation into myofibroblasts.

The differentiated nature of AS and NA HBFs (presented and summarized in Fig. 1) enabled the detection of dissimilarities in intracellular signalling pathway activity. The intensification of the output of pro-fibrotic proteins in bronchial fibroblasts from AS donors is probably dependent on the activation of different signalling pathways in comparison with their healthy counterparts.

Changes in ECM composition and stiffness have been shown to activate different signalling pathways (Fig. 2). Le Bellego et al. demonstrated that mechanical strain increased the secretion of pro-fibrotic and pro-inflammatory cytokines in bronchial fibroblasts obtained from AS patients, while no differences in cytokine secretion were observed in fibroblasts derived from normal volunteers [222]. Additionally, these authors revealed a mechanical strain-induced increase in ECM protein expression in only fibroblasts from AS subjects, which suggested that different signalling pathways are involved in the transduction of mechanical stimuli in AS and NA fibroblast populations [222]. In particular, mechanical 


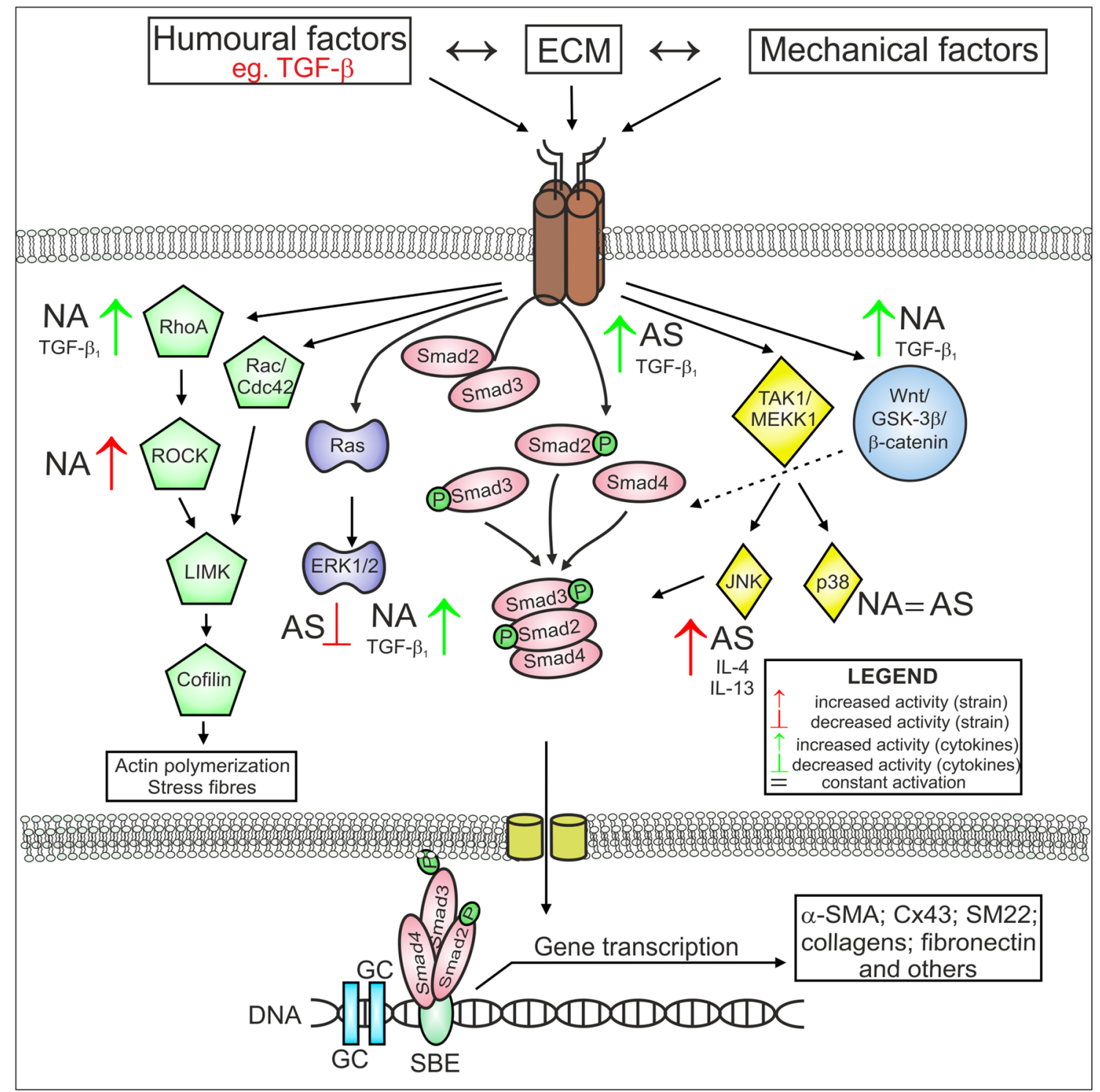

Fig. 2 Different activation of some signalling pathways stimulated by humoural and mechanical factors in AS and NA bronchial fibroblasts. This figure is a simplified illustration of the various signalling pathways, which are, in reality, far more complex than described here (some details in the text). AS bronchial fibroblasts from asthmatic subjects, NA bronchial fibroblasts from non-asthmatic donors

TGF- $\beta_{1}$-induced Smad-dependent signalling in AS HBFs is closely linked to the increased levels of $\mathrm{Cx} 43$ in these cells compared to NA counterparts [234]. It has been shown that Cx43 regulates FMT through competition with Smad2 for binding sites on microtubules and acts as a type of 'molecular switch' [234, 249-251].

Due to the pleiotropic properties of TGF- $\beta_{1}$, the induction of FMT during airway fibrosis is often associated with the activation of various non-canonical TGF- $\beta_{1}$-induced signalling pathways, e.g., the mitogen-activated protein kinase (MAPK) pathway. Activation of FMT via the ERK1/2 MAPK pathway was also observed in AS fibroblasts after the administration of bradykinin [204], IL-4 and IL-13 
[147] (Fig. 2). Moreover, inhibition of the p38 MAPK signalling pathway by SB203580 significantly attenuated the bradykinin-induced myofibroblastic transition of both NA and AS HBFs [204], but there are no reports concerning the effect of p38 MAPK signalling on TGF- $\beta_{1}$-induced FMT in these cells. Induction of the myofibroblastic transition of NA HLFs by TGF- $\beta$ is also associated with the activation of Rho-dependent signalling (Fig. 2) [235, 252]. On the other hand, it has been demonstrated that TGF- $\beta$-induced FMT in lung fibroblasts is associated with the activation of signalling via Wnt/GSK-3 $\beta / \beta$-catenin $[238,253]$. Michalik et al. found that inhibition of GSK-3 $\beta$ by $\mathrm{LiCl}$ or TWS119 attenuates TGF- $\beta_{1}$-induced FMT in HBF populations derived from AS patients but not in those from healthy donors (Fig. 2). Additionally, the administration of TGF- $\beta$ with inhibitors of Wnt/ GSK-3 $\beta / \beta$-catenin signalling (LiCL, TWS119) resulted in an increased level of $\beta$-catenin in NA HBFs compared to AS HBFs (Fig. 2). However, stimulation of AS HBFs by TGF- $\beta$ / LiCL led to attenuation of the Smad-dependent pathway. These reports suggest that impaired intracellular trafficking of $\beta$-catenin may be involved in the differences in reactivity of AS and NA HBFs to TGF- $\beta$-induced FMT via crosstalk with Smad-dependent signalling [238]. It appears that differences in Smad- or GSK-3//Wnt/ $\beta$-catenin-dependent pathway activity in AS HBFs after TGF- $\beta_{1}$ stimulation are closely associated with the cellular and molecular properties of these cells. In addition, different patterns of the above-mentioned proteins may be a response to the diverse activity of signalling pathways or may regulate their activity. However, the most likely scenario is the existence of inherent properties of cells that lead to the amplification of pro-fibrotic signals, which is supported by the intensified FMT potential of HBFs. Sources of phenotypic diversity among HBFs may be attributable to the origin of airway myofibroblast precursors.

Finally, the data mentioned above suggest that inherent lung/bronchial fibroblast features are as significant as growth factors and mechanical properties of the microenvironment surrounding the cell for the induction and effectiveness of FMT during asthma development.

Moreover, it is very important to realize that different populations of fibroblasts exist in the bronchial wall of AS subjects (Fig. 3). It was previously shown that within a single population of bronchial fibroblasts, there are cells (up to $20 \%$ ) insensitive to TGF- $\beta$-induced phenotypic transition [46, 223, 238, 254]. Moreover, unstimulated AS HBF populations show an enhanced percentage of $\alpha-\mathrm{SMA}^{+}$cells compared to NA counterparts $[46,223$, $238,255,256]$. The origin of this TGF- $\beta$-insensitive population is still unexplained but may be associated with the infiltration of highly contractile myofibroblast precursors, especially CD $34^{+}$fibrocytes, mesenchymal stem cells, adipocytes, and pericytes, into the pro-inflammatory niche of the bronchial wall. These features may also be linked to asthma heterogeneity, showing that the multidirectional mechanisms of asthma inevitably lead to the expansion of myofibroblasts and the development of subepithelial fibrosis.

It is also important to emphasize the impact of cellular interactions on FMT potential in fibroblasts. Recent reports have indicated that AS epithelial cells favour the accumulation of myofibroblasts and stimulate ECM production in human lung fibroblast populations [34, 224]. However, little is known about the behaviour of bronchial fibroblasts co-cultured with epithelial cells, especially because different FMT potentials are observed between fibroblast populations of human bronchial and lung parenchyma (Fig. 3) [257, 258]. Finally, the effects of the differentiated features of bronchial fibroblasts can also be attributed to epigenetic or genetic factors (Fig. 3). Even though the impact of these (genetic and/or epigenetic) factors on asthma progression has been presented by others [259-262], little is known about the genetic and epigenetic factors directly affecting the differential response of bronchial fibroblasts to pro-inflammatory signals.
Fig. 3 Factors affecting fibroblast-to-myofibroblast transition during airway wall remodelling in bronchial asthma. FMT fibroblast-to-myofibroblast transition, $T G F-\beta$ transforming growth factor-beta $E M T U$ epithelial-mesenchymal trophic unit, $E C M$ extracellular matrix

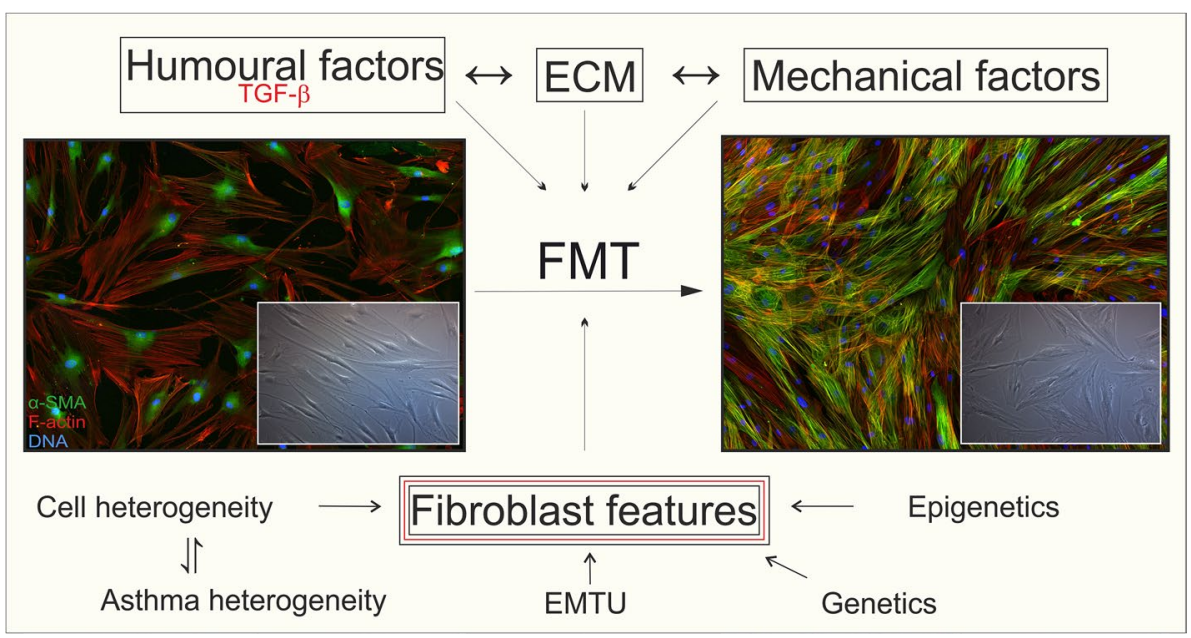




\section{Conclusion}

Multiple data summarized in this article clearly indicate for the first time that the induction of FMT, a process that occurs in AS bronchial walls, requires both extrinsic (humoural, mechanical and ECM interactions) factors and inherent properties of bronchial fibroblasts (Fig. 3). Despite the yet uncertain contribution of these factors to the decline in the lung function of AS subjects, it seems practical to acknowledge that the literature supports an intervention based on topical inhibition of pathways that lead to bronchial remodelling.

Open Access This article is distributed under the terms of the Creative Commons Attribution 4.0 International License (http://creativeco mmons.org/licenses/by/4.0/), which permits unrestricted use, distribution, and reproduction in any medium, provided you give appropriate credit to the original author(s) and the source, provide a link to the Creative Commons license, and indicate if changes were made.

\section{References}

1. Holgate ST (2008) Pathogenesis of asthma. Clin Exp Allergy 38(6):872-897. https://doi.org/10.1111/j.1365-2222.2008.02971 .X

2. Al-Muhsen S, Johnson JR, Hamid Q (2011) Remodeling in asthma. J Allergy Clin Immunol 128(3):451-462. https://doi. org/10.1016/j.jaci.2011.04.047

3. Elias JA, Zhu Z, Chupp G, Homer RJ (1999) Airway remodeling in asthma. J Clin Invest 104(8):1001-1006. https://doi. org/10.1172/JCI8124

4. Sumi Y, Hamid Q (2007) Airway remodeling in asthma. Allergol Int 56(4):341-348. https://doi.org/10.2332/allergolint.R-07-153

5. Mauad T, Bel EH, Sterk PJ (2007) Asthma therapy and airway remodeling. J Allergy Clin Immunol 120(5):997-1009. https:// doi.org/10.1016/j.jaci.2007.06.031

6. Keglowich LF, Borger P (2015) The three A's in asthma-airway smooth muscle, airway remodeling \& angiogenesis. Open Respir Med J 9:70-80. https://doi.org/10.2174/1874306401509010070

7. Hancox RJ, Pavord ID, Sears MR (2018) Associations between blood eosinophils and decline in lung function among adults with and without asthma. Eur Respir J 51(4):1702536. https:// doi.org/10.1183/13993003.02536-2017

8. Reynolds CJ, Quigley K, Cheng X, Suresh A, Tahir S, AhmedJushuf F, Nawab K, Choy K, Walker SA, Mathie SA, Sim M, Stowell J, Manji J, Pollard T, Altmann DM, Boyton RJ (2018) Lung defense through interleukin- 8 carries a cost of chronic lung remodeling and impaired function. Am J Respir Cell Mol Biol. https://doi.org/10.1165/rcmb.2018-0007OC

9. Payne DN, Rogers AV, Adelroth E, Bandi V, Guntupalli KK, Bush A, Jeffery PK (2003) Early thickening of the reticular basement membrane in children with difficult asthma. Am J Respir Crit Care Med 167(1):78-82. https://doi.org/10.1164/rccm.20020 5-414OC

10. Xuan W, Peat JK, Toelle BG, Marks GB, Berry G, Woolcock AJ (2000) Lung function growth and its relation to airway hyperresponsiveness and recent wheeze. Results from a longitudinal population study. Am J Respir Crit Care Med 161(6):1820-1824. https://doi.org/10.1164/ajrccm.161.6.9809118
11. Bossley CJ, Fleming L, Gupta A, Regamey N, Frith J, Oates T, Tsartsali L, Lloyd CM, Bush A, Saglani S (2012) Pediatric severe asthma is characterized by eosinophilia and remodeling without $\mathrm{T}(\mathrm{H}) 2$ cytokines. J Allergy Clin Immunol 129(4):974-982. https ://doi.org/10.1016/j.jaci.2012.01.059

12. Jeffery PK, Godfrey RW, Adelroth E, Nelson F, Rogers A, Johansson SA (1992) Effects of treatment on airway inflammation and thickening of basement membrane reticular collagen in asthma. A quantitative light and electron microscopic study. Am Rev Respir Dis 145(4 Pt 1):890-899. https://doi.org/10.1164/ ajrccm/145.4_Pt_1.890

13. Marandi Y, Farahi N, Hashjin GS (2013) Asthma: beyond corticosteroid treatment. Arch Med Sci 9(3):521-526. https://doi. org/10.5114/aoms.2013.33179

14. Bourdin A, Kleis S, Chakra M, Vachier I, Paganin F, Godard P, Chanez P (2012) Limited short-term steroid responsiveness is associated with thickening of bronchial basement membrane in severe asthma. Chest 141(6):1504-1511. https://doi.org/10.1378/ chest.11-0232

15. Martinez FD (2009) The origins of asthma and chronic obstructive pulmonary disease in early life. Proc Am Thorac Soc 6(3):272-277. https://doi.org/10.1513/pats.200808-092RM

16. Kumar P, Ram U (2017) Patterns, factors associated and morbidity burden of asthma in India. PLoS One 12(10):e0185938. https ://doi.org/10.1371/journal.pone.0185938

17. Panek M, Mokros Ł, Pietras T, Kuna P (2016) The epidemiology of asthma and its comorbidities in Poland-Health problems of patients with severe asthma as evidenced in the Province of Lodz. Respir Med 112:31-38. https://doi.org/10.1016/j. rmed.2016.01.009

18. Liu Y, Li H, Xiao T, Lu Q (2013) Epigenetics in immune-mediated pulmonary diseases. Clin Rev Allergy Immunol 45(3):314 330. https://doi.org/10.1007/s12016-013-8398-3

19. Kanemitsu Y, Matsumoto H, Mishima M, the KiHAC Respiratory Medicine Group (2014) Factors contributing to an accelerated decline in pulmonary function in asthma. Allergol Int 63(2):181-188. https://doi.org/10.2332/allergolint.13-RA-0670

20. Patella V, Bocchino M, Steinhilber G (2015) Asthma is associated with increased susceptibility to infection. Minerva Med 106(4 Suppl 3):1-7

21. Chetta A, Foresi A, Del Donno M, Bertorelli G, Pesci A, Olivieri D (1997) Airways remodeling is a distinctive feature of asthma and is related to severity of disease. Chest 111(4):852-857. https ://doi.org/10.1378/chest.111.4.852

22. Little SA, Sproule MW, Cowan MD, Macleod KJ, Robertson M, Love JG, Chalmers GW, McSharry CP, Thomson NC (2002) High resolution computed tomographic assessment of airway wall thickness in chronic asthma: reproducibility and relationship with lung function and severity. Thorax 57(3):247-253. https:// doi.org/10.1136/thorax.57.3.247

23. Boulet LP, Laviolette M, Turcotte H, Cartier A, Dugas M, Malo JL, Boutet M (1997) Bronchial subepithelial fibrosis correlates with airway responsiveness to methacholine. Chest 112(1):4552. https://doi.org/10.1378/chest.112.1.45

24. Ebina M, Takahashi T, Chiba T, Motomiya M (1993) Cellular hypertrophy and hyperplasia of airway smooth muscles underlying bronchial asthma. A 3-D morphometric study. Am Rev Respir Dis 148(3):720-726. https://doi.org/10.1164/ajrcc $\mathrm{m} / 148.3 .720$

25. Benayoun L, Druilhe A, Dombret MC, Aubier M, Pretolani M (2003) Airway structural alterations selectively associated with severe asthma. Am J Respir Crit Care Med 167(10):1360-1368. https://doi.org/10.1164/rccm.200209-1030OC

26. Dekkers BG, Maarsingh H, Meurs H, Gosens R (2009) Airway structural components drive airway smooth muscle remodeling 
in asthma. Proc Am Thorac Soc 6(8):683-692. https://doi. org/10.1513/pats.200907-056DP

27. Begueret H, Berger P, Vernejoux JM, Dubuisson L, Marthan $R$, Tunon-de-Lara JM (2007) Inflammation of bronchial smooth muscle in allergic asthma. Thorax 62(1):8-15. https://doi. org/10.1136/thx.2006.062141

28. Woodruff PG, Dolganov GM, Ferrando RE, Donnelly S, Hays SR, Solberg OD, Carter R, Wong HH, Cadbury PS, Fahy JV (2004) Hyperplasia of smooth muscle in mild to moderate asthma without changes in cell size or gene expression. Am J Respir Crit Care Med 169(9):1001-1006. https://doi.org/10.1164/ rccm.200311-15290C

29. Aubier M, Thabut G, Hamidi F, Guillou N, Brard J, Dombret MC, Borensztajn K, Aitilalne B, Poirier I, Roland-Nicaise P, Taillé C, Pretolani M (2016) Airway smooth muscle enlargement is associated with protease-activated receptor 2/ligand overexpression in patients with difficult-to-control severe asthma. $\mathbf{J}$ Allergy Clin Immunol 138(3):729-739. https://doi.org/10.1016/j. jaci.2015.12.1332

30. Yamauchi K, Inoue H (2007) Airway remodeling in asthma and irreversible airflow limitation-ECM deposition in airway and possible therapy for remodeling. Allergol Int 56(4):321-329. https://doi.org/10.2332/allergolint.R-07-151

31. Royce SG, Tan L, Koek AA, Tang ML (2009) Effect of extracellular matrix composition on airway epithelial cell and fibroblast structure: implications for airway remodeling in asthma. Ann Allergy Asthma Immunol 102(3):238-346. https://doi. org/10.1016/S1081-1206(10)60087-7

32. Todorova L, Bjermer L, Westergren-Thorsson G, Miller-Larsson A (2011) TGF $\beta$-induced matrix production by bronchial fibroblasts in asthma: budesonide and formoterol effects. Respir Med 105(9):1296-1307. https://doi.org/10.1016/j.rmed.2011.03.020

33. Shifren A, Witt C, Christie C, Castro M (2012) Mechanisms of remodeling in asthmatic airways. J Allergy (Cairo) 2012:316049. https://doi.org/10.1155/2012/316049

34. Reeves SR, Kolstad T, Lien TY, Elliott M, Ziegler SF, Wight TN, Debley JS (2014) Asthmatic airway epithelial cells differentially regulate fibroblast expression of extracellular matrix components. J Allergy Clin Immunol 134(3):663-670. https:// doi.org/10.1016/j.jaci.2014.04.007

35. Leslie KO, Mitchell J, Low R (1992) Lung myofibroblasts. Cell Motil Cytoskeleton 22:92-98. https://doi.org/10.1002/cm.97022 0203

36. Wicks J, Haitchi HM, Holgate ST, Davies DE, Powell RM (2006) Enhanced upregulation of smooth muscle related transcripts by TGF $\beta 2$ in asthmatic (myo) fibroblasts. Thorax 61(4):313-319. https://doi.org/10.1136/thx.2005.050005

37. Larsen K, Malmström J, Wildt M, Dahlqvist C, Hansson L, Marko-Varga G, Bjermer L, Scheja A, Westergren-Thorsson G (2006) Functional and phenotypical comparison of myofibroblasts derived from biopsies and bronchoalveolar lavage in mild asthma and scleroderma. Respir Res 7:11. https://doi. org/10.1186/1465-9921-7-11

38. Singh SR, Hall IP (2008) Airway myofibroblasts and their relationship with airway myocytes and fibroblasts. Proc Am Thorac Soc 5(1):127-132. https://doi.org/10.1513/pats.200706-070VS

39. Samitas K, Zervas E, Vittorakis S, Semitekolou M, Alissafi T, Bossios A, Gogos H, Economidou E, Lötvall J, Xanthou G, Panoutsakopoulou V, Gaga M (2011) Osteopontin expression and relation to disease severity in human asthma. Eur Respir $\mathbf{J}$ 37(2):331-341. https://doi.org/10.1183/09031936.00017810

40. Hinz B, Phan SH, Thannickal VJ, Prunotto M, Desmoulière A, Varga J, De Wever O, Mareel M, Gabbiani G (2012) Recent developments in myofibroblast biology: paradigms for connective tissue remodeling. Am J Pathol 180(4):1340-1355. https:// doi.org/10.1016/j.ajpath.2012.02.004
41. Carthy JM (2018) TGF $\beta$ signaling and the control of myofibroblast differentiation: implications for chronic inflammatory disorders. J Cell Physiol 233(1):98-106. https://doi.org/10.1002/ jcp. 25879

42. Hinz B, Gabbiani G (2003) Cell-matrix and cell-cell contacts of myofibroblasts: role in connective tissue remodeling. Thromb Haemost 90(6):993-1002. https://doi.org/10.1160/ TH03-05-0328

43. Thannickal VJ, Lee DY, White ES, Cui Z, Larios JM, Chacon R, Horowitz JC, Day RM, Thomas PE (2003) Myofibroblast differentiation by transforming growth factor-betal is dependent on cell adhesion and integrin signaling via focal adhesion kinase. $\mathrm{J}$ Biol Chem 278(14):12384-12389. https://doi.org/10.1074/jbc. M208544200

44. Sarna M, Wojcik KA, Hermanowicz P, Wnuk D, Burda K, Sanak M, Czyż J, Michalik M (2015) Undifferentiated bronchial fibroblasts derived from asthmatic patients display higher elastic modulus than their non-asthmatic counterparts. PLoS ONE 10(2):e0116840. https://doi.org/10.1371/journal.pone.0116840

45. Darby IA, Zakuan N, Billet F, Desmoulière A (2016) The myofibroblast, a key cell in normal and pathological tissue repair. Cell Mol Life Sci 73(6):1145-1157. https://doi.org/10.1007/s0001 8-015-2110-0

46. Michalik M, Pierzchalska M, Legutko A, Ura M, Ostaszewska A, Soja J, Sanak M (2009) Asthmatic bronchial fibroblasts demonstrate enhanced potential to differentiate into myofibroblasts in culture. Med Sci Monit 15(7):BR194-BR201

47. Matis B, Bunu C, Tanasie G, Tatu C, Bojin F, Tatu C, Gavriliuc O, Cernescu L, Campean AM, Raica M, Paunescu V (2010) The effect of proinflammatory cytokines on pulmonary fibroblasts phenotype - a key role in airway remodeling in asthma. TMJ 60(2-3):183-188

48. Nam YH, Lee SK, Sammut D, Davies DE, Howarth PH (2012) Preliminary study of the cellular characteristics of primary bronchial fibroblasts in patients with asthma: expression of alpha-smooth muscle actin, fibronectin containing extra type III domain A, and smoothelin. J Investig Allergol Clin Immunol 22(1):20-27

49. Roche WR, Beasley R, Williams JH, Holgate ST (1989) Subepithelial fibrosis in the bronchi of asthmatics. Lancet 1(8637):520 524. https://doi.org/10.1016/S0140-6736(89)90067-6

50. Weitoft M, Andersson C, Andersson-Sjöland A, Tufvesson E, Bjermer L, Erjefält J, Westergren-Thorsson G (2014) Controlled and uncontrolled asthma display distinct alveolar tissue matrix compositions. Respir Res 15:67. https://doi. org/10.1186/1465-9921-15-67

51. Karjalainen EM, Lindqvist A, Laitinen LA, Kava T, Altraja A, Halme M, Laitinen A (2003) Airway inflammation and basement membrane tenascin in newly diagnosed atopic and nonatopic asthma. Respir Med 97(9):1045-1051. https://doi.org/10.1016/ S0954-6111(03)00136-7

52. Huang J, Olivenstein R, Taha R, Hamid Q, Ludwig M (1999) Enhanced proteoglycan deposition in the airway wall of atopic asthmatics. Am J Respir Crit Care Med 160:725-729. https://doi. org/10.1164/ajrccm.160.2.9809040

53. de Medeiros MM, da Silva LF, dos Santos MA, Fernezlian S, Schrumpf JA, Roughley P, Hiemstra PS, Saldiva PH, Mauad T, Dolhnikoff M (2005) Airway proteoglycans are differentially altered in fatal asthma. J Pathol 207:102-110. https://doi. org/10.1002/path.1818

54. Brewster CE, Howarth PH, Djukanovic R, Wilson J, Holgate ST, Roche WR (1990) Myofibroblasts and subepithelial fibrosis in bronchial asthma. Am J Respir Cell Mol Biol 3(5):507-511. https://doi.org/10.1165/ajrcmb/3.5.507

55. Wilson JW, Li X (1997) The measurement of reticular basement membrane and submucosal collagen in the 
asthmatic airway. Clin Exp Allergy 27(4):363-371. https://doi. org/10.1111/j.1365-2222.1997.tb00720.x

56. Hoshino M, Nakamura Y, Sim JJ (1998) Expression of growth factors and remodelling of the airway wall in bronchial asthma. Thorax 53:21-27. https://doi.org/10.1136/thx.53.1.21

57. Chu HW, Halliday JL, Martin RJ, Leung DYM, Szefler SJ, Wenzel SE (1998) Collagen deposition in large airways may not differentiate severe asthma from milder forms of the disease. Am J Respir Crit Care Med 158:1936-1944. https://doi.org/10.1164/ ajrccm.158.6.9712073

58. Gueders MM, Foidart JM, Noel A, Cataldo DD (2006) Matrix metalloproteinases (MMPs) and tissue inhibitors of MMPs in the respiratory tract: potential implications in asthma and other lung diseases. Eur J Pharmacol 533(1-3):133-144. https://doi. org/10.1016/j.ejphar.2005.12.082

59. Kelly EA, Busse WW, Jarjour NN (2000) Increased matrix metalloproteinase-9 in the airway after allergen challenge. Am J Respir Crit Care Med 162(3 Pt 1):1157-1161. https://doi.org/10.1164/ ajrccm.162.3.9908016

60. Vignola AM, Paganin F, Capieu L, Scichilone N, Bellia M, Maakel L, Bellia V, Godard P, Bousquet J, Chanez P (2004) Airway remodelling assessed by sputum and high-resolution computed tomography in asthma and COPD. Eur Respir J 24(6):910-917. https://doi.org/10.1183/09031936.04.00032603

61. Mohamed GM, Farres MN, Mahmoud H (2012) Interplay between matrix metalloproteinase- 9 and tissue inhibitor of matrix metalloproteinase- 1 in acute asthma exacerbation and airway remodeling. Egypt J Chest Dis Tuberc 61(3):35-39. https ://doi.org/10.1016/j.ejcdt.2012.10.020

62. Farhat AA, Mohamad AS, Shareef MM, Attia GA, Eid MA, Taha RW (2014) Asthma remodeling: the pathogenic role of matrix metalloproteinase-9. Egypt J Chest Dis Tuberc 63(4):755-759. https://doi.org/10.1016/j.ejcdt.2014.07.017

63. Zhang S, Howarth PH, Roche WR (1996) Cytokine production by cell cultures from bronchial subepithelial myofibroblasts. J Pathol 180(1):95-101. https://doi.org/10.1002/(SICI)10969896(199609)180:1\%3c95:AID-PATH614\%3e3.0.CO;2-B

64. Ward JE, Harris T, Bamford T, Mast A, Pain MC, Robertson C, Smallwood D, Tran T, Wilson J, Stewart AG (2008) Proliferation is not increased in airway myofibroblasts isolated from asthmatics. Eur Respir J 32(2):362-371. https://doi.org/10.1183/09031 936.00119307

65. Frieri M, Capetandes A (2008) The effect of enantiomers of beta-agonists on myofibroblast-derived vascular endothelial growth factor and other matrix components in the presence of dust-mite extract. Allergy Asthma Proc 29(2):182-188. https:// doi.org/10.2500/aap.2008.29.3096

66. Akamatsu T, Arai Y, Kosugi I, Kawasaki H, Meguro S, Sakao M, Shibata K, Suda T, Chida K, Iwashita T (2013) Direct isolation of myofibroblasts and fibroblasts from bleomycin-injured lungs reveals their functional similarities and differences. Fibrogenesis Tissue Repair 6(1):15. https://doi.org/10.1186/1755-1536-6-15

67. Freyer AM, Johnson SR, Hall IP (2001) Effects of growth factors and extracellular matrix on survival of human airway smooth muscle cells. Am J Respir Cell Mol Biol 25(5):569-576. https:// doi.org/10.1165/ajrcmb.25.5.4605

68. Salter B, Pray C, Radford K, Martin JG, Nair P (2017) Regulation of human airway smooth muscle cell migration and relevance to asthma. Respir Res 18(1):156. https://doi.org/10.1186/s1293 1-017-0640-8

69. Kim KK, Wei Y, Szekeres C, Kugler MC, Wolters PJ, Hill ML, Frank JA, Brumwell AN, Wheeler SE, Kreidberg JA, Chapman HA (2009) Epithelial cell alpha3beta1 integrin links beta-catenin and Smad signaling to promote myofibroblast formation and pulmonary fibrosis. J Clin Invest 119(1):213-224. https://doi. org/10.1172/JCI36940

70. Willis BC, Liebler JM, Luby-Phelps K, Nicholson AG, Crandall ED, du Bois RM, Borok Z (2005) Induction of epithelialmesenchymal transition in alveolar epithelial cells by transforming growth factor-beta1: potential role in idiopathic pulmonary fibrosis. Am J Pathol 166(5):1321-1332. https://doi.org/10.1016/ S0002-9440(10)62351-6

71. Yang ZC, Yi MJ, Ran N, Wang C, Fu P, Feng XY, Xu L, Qu ZH (2013) Transforming growth factor- $\beta 1$ induces bronchial epithelial cells to mesenchymal transition by activating the Snail pathway and promotes airway remodeling in asthma. Mol Med Rep 8(6):1663-1668. https://doi.org/10.3892/mmr.2013.1728

72. Pain M, Bermudez O, Lacoste P, Royer PJ, Botturi K, Tissot A, Brouard S, Eickelberg O, Magnan A (2014) Tissue remodelling in chronic bronchial diseases: from the epithelial to mesenchymal phenotype. Eur Respir Rev 23(131):118-130. https://doi. org/10.1183/09059180.00004413

73. Hashimoto N, Phan SH, Imaizumi K, Matsuo M, Nakashima H, Kawabe T, Shimokata K, Hasegawa Y (2010) Endothelialmesenchymal transition in bleomycin-induced pulmonary fibrosis. Am J Respir Cell Mol Biol 43(2):161-172. https://doi. org/10.1165/rcmb.2009-00310C

74. Bellini A, Mattoli S (2007) The role of the fibrocyte, a bone marrow-derived mesenchymal progenitor, in reactive and reparative fibroses. Lab Invest 87(9):858-870. https://doi.org/10.1038/ labinvest.3700654

75. Schmidt M, Sun G, Stacey MA, Mori L, Mattoli S (2003) Identification of circulating fibrocytes as precursors of bronchial myofibroblasts in asthma. J Immunol 171(1):380-389. https:// doi.org/10.4049/jimmunol.171.1.380

76. Nihlberg K, Larsen K, Hultgårdh-Nilsson A, Malmström A, Bjermer L, Westergren-Thorsson G (2006) Tissue fibrocytes in patients with mild asthma: a possible link to thickness of reticular basement membrane? Respir Res 7:50. https://doi. org/10.1186/1465-9921-7-50

77. Mori L, Bellini A, Stacey MA, Schmidt M, Mattoli S (2005) Fibrocytes contribute to the myofibroblast population in wounded skin and originate from the bone marrow. Exp Cell Res 304(1):81-90. https://doi.org/10.1016/j.yexcr.2004.11.011

78. Wang CH, Huang CD, Lin HC, Lee KY, Lin SM, Liu CY, Huang KH, Ko YS, Chung KF, Kuo HP (2008) Increased circulating fibrocytes in asthma with chronic airflow obstruction. Am J Respir Crit Care Med 178(6):583-591. https://doi.org/10.1164/ rccm.200710-15570C

79. Weng CM, Chen BC, Wang CH, Feng PH, Lee MJ, Huang CD, Kuo HP, Lin CH (2013) The endothelin A receptor mediates fibrocyte differentiation in chronic obstructive asthma. The involvement of connective tissue growth factor. Am J Respir Crit Care Med 188(3):298-308. https://doi.org/10.1164/rccm.20130 1-0132OC

80. Phillips RJ, Burdick MD, Hong K, Lutz MA, Murray LA, Xue YY, Belperio JA, Keane MP, Strieter RM (2004) Circulating fibrocytes traffic to the lungs in response to CXCL12 and mediate fibrosis. J Clin Invest 114(3):438-446. https://doi.org/10.1172/ JCI20997

81. Fischer KD, Agrawal DK (2013) Hematopoietic stem and progenitor cells in inflammation and allergy. Front Immunol 4:428. https://doi.org/10.3389/fimmu.2013.00428

82. Lo CY, Michaeloudes C, Bhavsar PK, Huang CD, Wang CH, Kuo HP, Chung KF (2015) Increased phenotypic differentiation and reduced corticosteroid sensitivity of fibrocytes in severe asthma. J Allergy Clin Immunol 135(5):1186-1195. https://doi. org/10.1016/j.jaci.2014.10.031 
83. Rowley JE, Johnson JR (2014) Pericytes in chronic lung disease. Int Arch Allergy Immunol 164(3):178-188. https://doi. org/10.1159/000365051

84. Johnson JR, Folestad E, Rowley JE, Noll EM, Walker SA, Lloyd CM, Rankin SM, Pietras K, Eriksson U, Fuxe J (2015) Pericytes contribute to airway remodeling in a mouse model of chronic allergic asthma. Am J Physiol Lung Cell Mol Physiol 308(7):658-671. https://doi.org/10.1152/ajplung.00286.2014

85. Zhang S, Smartt H, Holgate ST, Roche WR (1999) Growth factors secreted by bronchial epithelial cells control myofibroblast proliferation: an in vitro co-culture model of airway remodeling in asthma. Lab Invest 79(4):395-405

86. Larsen K, Tufvesson E, Malmström J, Mörgelin M, Wildt M, Andersson A, Lindström A, Malmström A, Löfdahl CG, Marko-Varga G, Bjermer L, Westergren-Thorsson G (2004) Presence of activated mobile fibroblasts in bronchoalveolar lavage from patients with mild asthma. Am J Respir Crit Care Med 170(10):1049-1056. https://doi.org/10.1164/rccm.20040 4-507OC

87. Gabbiani G, Ryan GB, Majne G (1971) Presence of modified fibroblasts in granulation tissue and their possible role in wound contraction. Experientia 27(5):549-550. https://doi.org/10.1007/ BF02147594

88. Tomasek JJ, Gabbiani G, Hinz B, Chaponnier C, Brown RA (2002) Myofibroblasts and mechano-regulation of connective tissue remodelling. Nat Rev Mol Cell Biol 3(5):349-363. https ://doi.org/10.1038/nrm809

89. Balza E, Borsi L, Allemanni G, Zardi L (1988) Transforming growth factor beta regulates the levels of different fibronectin isoforms in normal human cultured fibroblasts. FEBS Lett 228(1):42-44. https://doi.org/10.1016/0014-5793(88)80580-5

90. Malmström J, Tufvesson E, Löfdahl CG, Hansson L, MarkoVarga G, Westergren-Thorsson G (2003) Activation of plateletderived growth factor pathway in human asthmatic pulmonaryderived mesenchymal cells. Electrophoresis 24(1-2):276-285. https://doi.org/10.1002/elps.200390024

91. Hinz B, Pittet P, Smith-Clerc J, Chaponnier C, Meister JJ (2004) Myofibroblast development is characterized by specific cell-cell adherens junctions. Mol Biol Cell 15(9):4310-4320. https://doi. org/10.1091/mbc.e04-05-0386

92. Hecker L, Jagirdar R, Jin T, Thannickal VJ (2011) Reversible differentiation of myofibroblasts by MyoD. Exp Cell Res 317(13):1914-1921. https://doi.org/10.1016/j.yexcr.2011.03.016

93. Wettlaufer SH, Scott JP, McEachin RC, Peters-Golden M, Huang SK (2016) Reversal of the transcriptome by prostaglandin E2 during myofibroblast dedifferentiation. Am J Respir Cell Mol Biol 54(1):114-127. https://doi.org/10.1165/rcmb.2014-0468OC

94. Burgess JK, Mauad T, Tjin G, Karlsson JC, Westergren-Thorsson G (2016) The extracellular matrix - the under-recognized element in lung disease? J Pathol 240(4):397-409. https://doi. org/10.1002/path.4808

95. Howell JE, McAnulty RJ (2006) TGF-beta: its role in asthma and therapeutic potential. Curr Drug Targets 7(5):547-565. https:// doi.org/10.2174/138945006776818692

96. Rahimi RA, Leof EB (2007) TGF-beta signaling: a tale of two responses. J Cell Biochem 102(3):593-608. https://doi. org/10.1002/jcb. 21501

97. Minshall EM, Leung DY, Martin RJ, Song YL, Cameron L, Ernst P, Hamid Q (1997) Eosinophil-associated TGF-beta1 mRNA expression and airways fibrosis in bronchial asthma. Am J Respir Cell Mol Biol 17(3):326-333. https://doi.org/10.1165/ ajrcmb.17.3.2733

98. Batra V, Musani AI, Hastie AT, Khurana S, Carpenter KA, Zangrilli JG, Peters SP (2004) Bronchoalveolar lavage fluid concentrations of transforming growth factor (TGF)-beta1, TGF-beta2, interleukin (IL)-4 and IL-13 after segmental allergen challenge and their effects on alpha-smooth muscle actin and collagen III synthesis by primary human lung fibroblasts. Clin Exp Allergy 34(3):437-444. https://doi.org/10.1111/j.1365-2222.2004.01885 . $\mathrm{x}$

99. Balzar S, Chu HW, Silkoff P, Cundall M, Trudeau JB, Strand M, Wenzel S (2005) Increased TGF-beta2 in severe asthma with eosinophilia. J Allergy Clin Immunol 115(1):110-117. https:// doi.org/10.1016/j.jaci.2004.09.034

100. Bossé Y, Rola-Pleszczynski M (2007) Controversy surrounding the increased expression of TGF $\beta 1$ in asthma. Respir Res 8(1):66. https://doi.org/10.1186/1465-9921-8-66

101. Torrego A, Hew M, Oates T, Sukkar M, Chung KF (2007) Expression and activation of TGF- $\beta$ isoforms in acute allergeninduced remodelling in asthma. Thorax 62(4):307-313. https:// doi.org/10.1136/thx.2006.063487

102. Manuyakorn W, Kamchaisatian W, Atamasirikul K, Sasisakulporn C, Direkwattanachai C, Benjaponpitak S (2008) Serum TGF- $\beta 1$ in atopic asthma. Asian Pac J Allergy Immunol 26(4):185-189

103. Lopez-Guisa JM, Powers C, File D, Cochrane E, Jimenez N, Debley JS (2012) Airway epithelial cells from asthmatic children differentially express proremodeling factors. J Allergy Clin Immunol 129(4):990-997. https://doi.org/10.1016/j.jaci.2011.11.035

104. Redington AE, Madden J, Frew AJ, Djukanovic R, Roche WR, Holgate ST, Howarth PH (1997) Transforming growth factor-beta 1 in asthma. Measurement in bronchoalveolar lavage fluid. Am J Respir Crit Care Med 156(2):642-647. https://doi.org/10.1164/ ajrccm.156.2.9605065

105. Chu HW, Trudeau JB, Balzar S, Wenzel SE (2000) Peripheral blood and airway tissue expression of transforming growth factor beta by neutrophils in asthmatic subjects and normal control subjects. J Allergy Clin Immunol 106(6):1115-1123. https://doi. org/10.1067/mai.2000.110556

106. Chakir J, Shannon J, Molet S, Fukakusa M, Elias J, Laviolette M, Boulet LP, Hamid Q (2003) Airway remodeling-associated mediators in moderate to severe asthma: effect of steroids on TGF-beta, IL-11, IL-17, and type I and type III collagen expression. J Allergy Clin Immunol 111(6):1293-1298. https://doi. org/10.1067/mai.2003.1557

107. Ohno I, Nitta Y, Yamauchi K, Hoshi H, Honma M, Woolley K, O’Byrne P, Tamura G, Jordana M, Shirato K (1996) Transforming growth factor beta 1 (TGF beta 1 ) gene expression by eosinophils in asthmatic airway inflammation. Am J Respir Cell Mol Biol 15(3):404-409. https://doi.org/10.1165/ajrcmb.15.3.88106 46

108. Aubert JD, Dalal BI, Bai TR, Roberts CR, Hayashi S, Hogg JC (1994) Transforming growth factor beta 1 gene expression in human airways. Thorax 49(3):225-232. https://doi.org/10.1136/ thx.49.3.225

109. Redington AE, Roche WR, Holgate ST, Howarth PH (1998) Co-localization of immunoreactive transforming growth factor-beta 1 and decorin in bronchial biopsies from asthmatic and normal subjects. J Pathol 186(4):410-415. https://doi. org/10.1002/(SICI)1096-9896(199812)186:4\%3c410:AIDPATH198\%3e3.0.CO;2-9

110. Duvernelle C, Freund V, Frossard N (2003) Transforming growth factor-beta and its role in asthma. Pulm Pharmacol Ther 16(4):181-196. https://doi.org/10.1016/S1094-5539(03)00051-8

111. Breton JD, Heydet D, Starrs LM, Veldre T, Ghildyal R (2018) Molecular changes during TGF $\beta$-mediated lung fibroblast-myofibroblast differentiation: implication for glucocorticoid resistance. Physiol Rep 6(7):e13669. https://doi.org/10.14814/phy2.13669

112. Xie S, Sukkar MB, Issa R, Khorasani NM, Chung KF (2007) Mechanisms of induction of airway smooth muscle hyperplasia 
by transforming growth factor-beta. Am J Physiol Lung Cell Mol Physiol 293(1):L245-L253. https://doi.org/10.1152/ajplu ng.00068.2007

113. Ling KM, Sutanto EN, Iosifidis T, Kicic-Starcevich E, Looi K, Garratt LW, Martinovich KM, Lannigan FJ, Knight DA, Stick SM, Kicic A (2016) Reduced transforming growth factor $\beta 1$ (TGF- $\beta 1$ ) in the repair of airway epithelial cells of children with asthma. Respirology 21(7):1219-1226. https://doi.org/10.1111/ resp. 12810

114. Zhang Y, Tang H, Yuan X, Ran Q, Wang X, Song Q, Zhang L, Qiu Y, Wang X (2018) TGF- $\beta 3$ promotes MUC5AC hyperexpression by modulating autophagy pathway in airway epithelium. EBioMedicine. https://doi.org/10.1016/j.ebiom 2018.06.032

115. Ojiaku CA, Yoo EJ, Panettieri RA Jr (2017) Transforming growth factor $\beta 1$ function in airway remodeling and hyperresponsiveness. The missing link? Am J Respir Cell Mol Biol 56(4):432442. https://doi.org/10.1165/rcmb.2016-0307TR

116. Al-Alawi M, Hassan T, Chotirmall SH (2014) Transforming growth factor $\beta$ and severe asthma: a perfect storm. Respir Med 108(10):1409-1423. https://doi.org/10.1016/j.rmed.2014.08.008

117. Hackett TL, Warner SM, Stefanowicz D, Shaheen F, Pechkovsky DV, Murray LA, Argentieri R, Kicic A, Stick SM, Bai TR, Knight DA (2009) Induction of epithelial-mesenchymal transition in primary airway epithelial cells from patients with asthma by transforming growth factor-beta1. Am J Respir Crit Care Med 180(2):122-133. https://doi.org/10.1164/rccm.200811-1730OC

118. Boero S, Sabatini F, Silvestri M, Petecchia L, Nachira A, Pezzolo A, Scarso L, Rossi GA (2007) Modulation of human lung fibroblast functions by ciclesonide: evidence for its conversion into the active metabolite desisobutyryl-ciclesonide. Immunol Lett 112(1):39-46. https://doi.org/10.1016/j.imlet.2007.06.010

119. Milara J, Serrano A, Peiró T, Gavaldà A, Miralpeix M, Morcillo EJ, Cortijo J (2012) Aclidinium inhibits human lung fibroblast to myofibroblast transition. Thorax 67(3):229-237. https://doi. org/10.1136/thoraxjnl-2011-200376

120. Sagara H, Okada T, Okumura K, Ogawa H, Ra C, Fukuda T, Nakao A (2002) Activation of TGF-beta/Smad2 signaling is associated with airway remodeling in asthma. J Allergy Clin Immunol 110(2):249-254. https://doi.org/10.1067/mai.2002.126078

121. Le AV, Cho JY, Miller M, McElwain S, Golgotiu K, Broide DH (2007) Inhibition of allergen-induced airway remodeling in Smad 3-deficient mice. J Immunol 178(11):7310-7316. https:// doi.org/10.4049/jimmunol.178.11.7310

122. Luo F, Zhuang Y, Sides MD, Sanchez CG, Shan B, White ES, Lasky JA (2014) Arsenic trioxide inhibits transforming growth factor- $\beta 1$-induced fibroblast to myofibroblast differentiation in vitro and bleomycin induced lung fibrosis in vivo. Respir Res 15(1):51. https://doi.org/10.1186/1465-9921-15-51

123. Gomes I, Mathur SK, Espenshade BM, Mori Y, Varga J, Ackerman SJ (2005) Eosinophil-fibroblast interactions induce fibroblast IL-6 secretion and extracellular matrix gene expression: implications in fibrogenesis. J Allergy Clin Immunol 116(4):796-804. https://doi.org/10.1016/j.jaci.2005.06.031

124. Khalil N, Xu YD, O'Connor R, Duronio V (2005) Proliferation of pulmonary interstitial fibroblasts is mediated by transforming growth factor-beta1-induced release of extracellular fibroblast growth factor-2 and phosphorylation of p38 MAPK and JNK. J Biol Chem 280(52):43000-43009. https://doi.org/10.1074/jbc. M510441200

125. Kobayashi T, Liu X, Wen FQ, Fang Q, Abe S, Wang XQ, Hashimoto M, Shen L, Kawasaki S, Kim HJ, Kohyama T, Rennard SI (2005) Smad3 mediates TGF-beta1 induction of VEGF production in lung fibroblasts. Biochem Biophys Res Commun 327(2):393-398. https://doi.org/10.1016/j.bbrc.2004.12.032
126. Wójcik K, Koczurkiewicz P, Michalik M, Sanak M (2012) Transforming growth factor- $\beta_{1}$-induced expression of connective tissue growth factor is enhanced in bronchial fibroblasts derived from asthmatic patients. Pol Arch Med Wewn 122(7-8):326-332

127. Wójcik-Pszczoła K, Jakieła B, Plutecka H, Koczurkiewicz P, Madeja Z, Michalik M, Sanak M (2018) Connective tissue growth factor regulates transition of primary bronchial fibroblasts to myofibroblasts in asthmatic subjects. Cytokine 102:187-190. https://doi.org/10.1016/j.cyto.2017.09.002

128. Wang J, Faiz A, Ge Q, Vermeulen CJ, Van der Velden J, Snibson KJ, van de Velde R, Sawant S, Xenaki D, Oliver B, Timens W, Ten Hacken N, van den Berge M, James A, Elliot JG, Dong L, Burgess JK, Ashton AW (2018) Unique mechanisms of connective tissue growth factor regulation in airway smooth muscle in asthma: relationship with airway remodelling. J Cell Mol Med 22(5):2826-2837. https://doi.org/10.1111/jcmm.13576

129. Kular L, Pakradouni J, Kitabgi P, Laurent M, Martinerie C (2011) The CCN family: a new class of inflammation modulators? Biochimie 93(3):377-388. https://doi.org/10.1016/j.bioch i. 2010.11 .010

130. Kato M, Fujisawa T, Hashimoto D, Kono M, Enomoto N, Nakamura Y, Inui N, Hamada E, Miyazaki O, Kurashita S, Maekawa M, Suda T (2014) Plasma connective tissue growth factor levels as potential biomarkers of airway obstruction in patients with asthma. Ann Allergy Asthma Immunol 113(3):295-300. https:// doi.org/10.1016/j.anai.2014.05.026

131. Xie S, Sukkar MB, Issa R, Oltmanns U, Nicholson AG, Chung KF (2005) Regulation of TGF-beta 1-induced connective tissue growth factor expression in airway smooth muscle cells. Am J Physiol Lung Cell Mol Physiol 288(1):L68-L76. https://doi. org/10.1152/ajplung.00156.2004

132. Burgess JK, Johnson PR, Ge Q, Au WW, Poniris MH, McParland BE, King G, Roth M, Black JL (2003) Expression of connective tissue growth factor in asthmatic airway smooth muscle cells. Am J Respir Crit Care Med 167(1):71-77. https://doi. org/10.1164/rccm.200205-416OC

133. Burgess JK, Ge Q, Poniris MH, Boustany S, Twigg SM, Black JL, Johnson PR (2006) Connective tissue growth factor and vascular endothelial growth factor from airway smooth muscle interact with the extracellular matrix. Am J Physiol Lung Cell Mol Physiol 290(1):L1531-L1561. https://doi.org/10.1152/ajplu ng.00287.2005

134. Johnson PR, Burgess JK, Ge Q, Poniris M, Boustany S, Twigg SM, Black JL (2006) Connective tissue growth factor induces extracellular matrix in asthmatic airway smooth muscle. Am J Respir Crit Care Med 173(1):32-41. https://doi.org/10.1164/ rccm.200406-703OC

135. Grotendorst GR, Rahmanie H, Duncan MR (2004) Combinatorial signaling pathways determine fibroblast proliferation and myofibroblast differentiation. FASEB J 18(3):469-479. https:// doi.org/10.1096/fj.03-0699com

136. Lewis CC, Chu HW, Westcott JY, Tucker A, Langmack EL, Sutherland ER, Kraft M (2005) Airway fibroblasts exhibit a synthetic phenotype in severe asthma. J Allergy Clin Immunol 115(3):534-540. https://doi.org/10.1016/j.jaci.2004.11.051

137. Dubé J, Chakir J, Laviolette M, Saint Martin S, Boutet M, Desrochers C, Auger F, Boulet LP (1998) In vitro procollagen synthesis and proliferative phenotype of bronchial fibroblasts from normal and asthmatic subjects. Lab Invest 78(3):297-307

138. Bonini S, Lambiase A, Bonini S, Angelucci F, Magrini L, Manni L, Aloe L (1996) Circulating nerve growth factor levels are increased in humans with allergic diseases and asthma. Proc Natl Acad Sci USA 93(20):10955-10960. https://doi.org/10.1073/ pnas.93.20.10955

139. Micera A, Vigneti E, Pickholtz D, Reich R, Pappo O, Bonini S, Maquart FX, Aloe L, Levi-Schaffer F (2001) Nerve growth factor 
displays stimulatory effects on human skin and lung fibroblasts, demonstrating a direct role for this factor in tissue repair. Proc Natl Acad Sci USA 98(11):6162-6167. https://doi.org/10.1073/ pnas. 101130898

140. Kohyama T, Liu X, Wen FQ, Kobayashi T, Abe S, Ertl R, Rennard SI (2002) Nerve growth factor stimulates fibronectininduced fibroblast migration. J Lab Clin Med 140(5):329-335. https://doi.org/10.1067/mlc.2002.128347

141. Frossard N, Freund V, Advenier C (2004) Nerve growth factor and its receptors in asthma and inflammation. Eur J Pharmacol 500(1-3):453-465. https://doi.org/10.1016/j.ejphar.2004.07.044

142. Yamashita $\mathrm{N}$, Tashimo $\mathrm{H}$, Ishida $\mathrm{H}$, Matsuo $\mathrm{Y}$, Arai $\mathrm{H}$, Nagase H, Adachi T, Ohta K (2005) Role of insulin-like growth factor-I in allergen-induced airway inflammation and remodeling. Cell Immunol 235(2):85-91. https://doi.org/10.1016/j.celli mm.2005.07.006

143. Chung KF (1986) Role of inflammation in the hyperreactivity of the airways in asthma. Thorax 41(9):657-662. https://doi. org/10.1136/thx.41.9.657

144. Murdoch JR, Lloyd CM (2010) Chronic inflammation and asthma. Mutat Res 690(1-2):24-39. https://doi.org/10.1016/j. mrfmmm.2009.09.005

145. Nakagome K, Nagata M (2011) Pathogenesis of airway inflammation in bronchial asthma. Auris Nasus Larynx 38(5):555-563. https://doi.org/10.1016/j.anl.2011.01.011

146. Saito A, Okazaki H, Sugawara I, Yamamoto K, Takizawa $H$ (2003) Potential action of IL-4 and IL-13 as fibrogenic factors on lung fibroblasts in vitro. Int Arch Allergy Immunol 132(2):168176. https://doi.org/10.1159/000073718

147. Hashimoto S, Gon Y, Takeshita I, Maruoka S, Horie T (2001) IL-4 and IL-13 induce myofibroblastic phenotype of human lung fibroblasts through c-Jun NH2-terminal kinase-dependent pathway. J Allergy Clin Immunol 107(6):1001-1008. https://doi. org/10.1067/mai.2001.114702

148. Doucet C, Brouty-Boyé D, Pottin-Clemenceau C, Jasmin C, Canonica GW, Azzarone B (1998) IL-4 and IL-13 specifically increase adhesion molecule and inflammatory cytokine expression in human lung fibroblasts. Int Immunol 10(10):1421-1433. https://doi.org/10.1172/JCI741

149. Kraft M, Lewis C, Pham D, Chu HW (2001) IL-4, IL-13, and dexamethasone augment fibroblast proliferation in asthma. J Allergy Clin Immunol 107(4):602-606. https://doi.org/10.1067/ mai.2001.113760

150. Lee YC, Lee KH, Lee HB, Rhee YK (2001) Serum levels of interleukins (IL)-4, IL-5, IL-13, and interferon-gamma in acute asthma. J Asthma 38(8):665-671. https://doi.org/10.1081/JAS100107544

151. Richter A, Puddicombe SM, Lordan JL, Bucchieri F, Wilson SJ, Djukanovic R, Dent G, Holgate ST, Davies DE (2001) The contribution of interleukin (IL)-4 and IL-13 to the epithelialmesenchymal trophic unit in asthma. Am J Respir Cell Mol Biol 25(3):385-391. https://doi.org/10.1165/ajrcmb.25.3.4437

152. Ingram JL, Rice A, Geisenhoffer K, Madtes DK, Bonner JC (2003) Interleukin-13 stimulates the proliferation of lung myofibroblasts via a signal transducer and activator of transcription-6-dependent mechanism: a possible mechanism for the development of airway fibrosis in asthma. Chest $123(3$ Suppl):422S-424S. https://doi.org/10.1378/chest.123.3_suppl $.422 \mathrm{~S}$

153. Ingram JL, Huggins MJ, Church TD, Li Y, Francisco DC, Degan S, Firszt R, Beaver DM, Lugogo NL, Wang Y, Sunday ME, Noble PW, Kraft M (2011) Airway fibroblasts in asthma manifest an invasive phenotype. Am J Respir Crit Care Med 183(12):16251632. https://doi.org/10.1164/rccm.201009-1452OC

154. Takayama G, Arima K, Kanaji T, Toda S, Tanaka H, Shoji S, McKenzie AN, Nagai H, Hotokebuchi T, Izuhara K (2006)
Periostin: a novel component of subepithelial fibrosis of bronchial asthma downstream of IL-4 and IL-13 signals. J Allergy Clin Immunol 118(1):98-104. https://doi.org/10.1016/j. jaci.2006.02.046

155. Suzuki T, Arakawa H, Mizuno T, Muramatsu K, Tadaki H, Takizawa T, Mochizuki H, Tokuyama K, Matsukura S, Morikawa A (2008) Differential regulation of eotaxin expression by dexamethasone in normal human lung fibroblasts. Am J Respir Cell Mol Biol 38(6):707-714. https://doi.org/10.1165/rcmb.20070337OC

156. Ingram JL, Kraft M (2012) IL-13 in asthma and allergic disease: asthma phenotypes and targeted therapies. J Allergy Clin Immunol 130(4):829-842. https://doi.org/10.1016/j.jaci.2012.06.034

157. Wen FQ, Kohyama T, Liu X, Zhu YK, Wang H, Kim HJ, Kobayashi T, Abe S, Spurzem JR, Rennard SI (2002) Interleukin-4- and interleukin-13-enhanced transforming growth factor-beta2 production in cultured human bronchial epithelial cells is attenuated by interferon-gamma. Am J Respir Cell Mol Biol 26(4):484-490. https://doi.org/10.1165/ajrcmb.26.4.4784

158. Firszt R, Francisco D, Church TD, Thomas JM, Ingram JL, Kraft M (2014) Interleukin-13 induces collagen type-1 expression through matrix metalloproteinase- 2 and transforming growth factor- $\beta 1$ in airway fibroblasts in asthma. Eur Respir J 43(2):464-473. https://doi.org/10.1183/09031936.00068712

159. Komiya K, Ohta S, Arima K, Ogawa M, Suzuki S, Mitamura Y, Nunomura S, Nanri Y, Yoshihara T, Kawaguchi A, Kadota JI, Rubin BK, Izuhara K (2017) Clarithromycin attenuates IL-13-induced periostin production in human lung fibroblasts. Respir Res 18(1):37. https://doi.org/10.1186/s1293 1-017-0519-8

160. Tang W, Geba GP, Zheng T, Ray P, Homer RJ, Kuhn C 3rd, Flavell RA, Elias JA (1996) Targeted expression of IL-11 in the murine airway causes lymphocytic inflammation, bronchial remodeling, and airways obstruction. J Clin Invest 98(12):28452853. https://doi.org/10.1172/JCI119113

161. Zhu Z, Lee CG, Zheng T, Chupp G, Wang J, Homer RJ, Noble PW, Hamid Q, Elias JA (2001) Airway inflammation and remodeling in asthma: lessons from interleukin 11 and interleukin 13 transgenic mice. Am J Respir Crit Care Med 164(10 Pt 2):S67S70. https://doi.org/10.1164/ajrccm.164.supplement_2.2106070

162. Hall SL, Baker T, Lajoie S, Richgels PK, Yang Y, McAlees JW, van Lier A, Wills-Karp M, Sivaprasad U, Acciani TH, LeCras TD, Myers JB, Kovacic MB, Lewkowich IP (2017) IL-17A enhances IL-13 activity by enhancing IL-13-induced signal transducer and activator of transcription 6 activation. $\mathrm{J}$ Allergy Clin Immunol 139(2):462-471. https://doi.org/10.1016/j. jaci.2016.04.037

163. Molet S, Hamid Q, Davoine F, Nutku E, Taha R, Pagé N, Olivenstein R, Elias J, Chakir J (2001) IL-17 is increased in asthmatic airways and induces human bronchial fibroblasts to produce cytokines. J Allergy Clin Immunol 108(3):430-438. https://doi. org/10.1067/mai.2001.117929

164. van den Berg A, Kuiper M, Snoek M, Timens W, Postma DS, Jansen HM, Lutter R (2005) Interleukin-17 induces hyperresponsive interleukin- 8 and interleukin- 6 production to tumor necrosis factor-alpha in structural lung cells. Am J Respir Cell Mol Biol 33(1):97-104. https://doi.org/10.1165/rcmb.2005-0022OC

165. Peters M, Köhler-Bachmann S, Lenz-Habijan T, Bufe A (2016) Influence of an allergen-specific Th17 response on remodeling of the airways. Am J Respir Cell Mol Biol 54(3):350-358. https ://doi.org/10.1165/rcmb.2014-0429OC

166. Lei L, Zhao C, Qin F, He ZY, Wang X, Zhong XN (2016) Th17 cells and IL-17 promote the skin and lung inflammation and fibrosis process in a bleomycin-induced murine model of systemic sclerosis. Clin Exp Rheumatol 100(5):14-22 
167. Létuvé S, Lajoie-Kadoch S, Audusseau S, Rothenberg ME, Fiset PO, Ludwig MS, Hamid Q (2006) IL-17E upregulates the expression of proinflammatory cytokines in lung fibroblasts. $\mathbf{J}$ Allergy Clin Immunol 117(3):590-596. https://doi.org/10.1016/j. jaci.2005.10.025

168. Gregory LG, Jones CP, Walker SA, Sawant D, Gowers KH, Campbell GA, McKenzie AN, Lloyd CM (2013) IL-25 drives remodelling in allergic airways disease induced by house dust mite. Thorax 68(1):82-90. https://doi.org/10.1136/thoraxjnl2012-202003

169. Yao X, Wang W, Li Y, Lv Z, Guo R, Corrigan CJ, Ding G, Huang K, Sun Y, Ying S (2015) Characteristics of IL-25 and allergeninduced airway fibrosis in a murine model of asthma. Respirology 20(5):730-738. https://doi.org/10.1111/resp.12546

170. Yao X, Sun Y, Wang W, Sun Y (2016) Interleukin (IL)-25: pleiotropic roles in asthma. Respirology 21(4):638-647. https ://doi.org/10.1111/resp.12707

171. Kurokawa M, Matsukura S, Kawaguchi M, Ieki K, Suzuki S, Odaka M, Watanabe S, Homma T, Sato M, Yamaguchi M, Takeuchi H, Adachi M (2011) Expression and effects of IL-33 and ST2 in allergic bronchial asthma: IL-33 induces eotaxin production in lung fibroblasts. Int Arch Allergy Immunol 155(1):12-20. https://doi.org/10.1159/000327259

172. Guo Z, Wu J, Zhao J, Liu F, Chen Y, Bi L, Liu S, Dong L (2014) IL-33 promotes airway remodeling and is a marker of asthma disease severity. J Asthma 51(8):863-869. https://doi. org/10.3109/02770903.2014.921196

173. Nagahama KY, Togo S, Holz O, Magnussen H, Liu X, Seyama K, Takahashi K, Rennard SI (2013) Oncostatin M modulates fibroblast function via signal transducers and activators of transcription proteins-3. Am J Respir Cell Mol Biol 49(4):582591. https://doi.org/10.1165/rcmb.2012-04600C

174. Minshall E, Chakir J, Laviolette M, Molet S, Zhu Z, Olivenstein R, Elias JA, Hamid Q (2000) IL-11 expression is increased in severe asthma: association with epithelial cells and eosinophils. J Allergy Clin Immunol 105(2 Pt 1):232-238. https://doi.org/10.1016/S0091-6749(00)90070-8

175. Joseph J, Benedict S, Safa W, Joseph M (2004) Serum interleukin-5 levels are elevated in mild and moderate persistent asthma irrespective of regular inhaled glucocorticoid therapy. BMC Pulm Med 17(4):2. https://doi.org/10.1186/1471-2466-4-2

176. Simpson JL, Baines KJ, Boyle MJ, Scott RJ, Gibson PG (2009) Oncostatin M (OSM) is increased in asthma with incompletely reversible airflow obstruction. Exp Lung Res 35(9):781-794. https://doi.org/10.3109/01902140902906412

177. Beale J, Jayaraman A, Jackson DJ, Macintyre JDR, Edwards MR, Walton RP, Zhu J, Man Ching Y, Shamji B, Edwards M, Westwick J, Cousins DJ, Yi Hwang Y, McKenzie A, Johnston SL, Bartlett NW (2014) Rhinovirus-induced IL-25 in asthma exacerbation drives type 2 immunity and allergic pulmonary inflammation. Sci Transl Med 6(256):256ra134. https://doi. org/10.1126/scitranslmed.3009124

178. Pothoven KL, Norton JE, Hulse KE, Suh LA, Carter RG, Rocci E, Harris KE, Shintani-Smith S, Conley DB, Chandra RK, Liu MC, Kato A, Gonsalves N, Grammer LC, Peters AT, Kern RC, Bryce PJ, Tan BK, Schleimer RP (2015) Oncostatin $\mathrm{M}$ promotes mucosal epithelial barrier dysfunction, and its expression is increased in patients with eosinophilic mucosal disease. J Allergy Clin Immunol 136(3):737-746. https://doi. org/10.1016/j.jaci.2015.01.043

179. Lv H, Lu B, Qian XJ, Huang JA, Qiu TF (2016) Serum IL-17 \& eotaxin levels in asthmatic patients with allergic rhinitis. Pak J Med Sci 32(3):700-704. https://doi.org/10.12669/ pjms.323.9914

180. Hasegawa T, Uga H, Mori A, Kurata H (2017) Increased serum IL-17A and Th2 cytokine levels in patients with severe uncontrolled asthma. Eur Cytokine Netw 28(1):8-18. https://doi. org/10.1684/ecn.2017.0390

181. Conroy DM, Williams TJ (2001) Eotaxin and the attraction of eosinophils to the asthmatic lung. Respir Res 2(3):150-156. https ://doi.org/10.1186/rr52

182. Ravensberg AJ, Ricciardolo FL, van Schadewijk A, Rabe KF, Sterk PJ, Hiemstra PS, Mauad T (2005) Eotaxin-2 and eotaxin-3 expression is associated with persistent eosinophilic bronchial inflammation in patients with asthma after allergen challenge. J Allergy Clin Immunol 115(4):779-785. https://doi.org/10.1016/j. jaci.2004.11.045

183. Puxeddu I, Bader R, Piliponsky AM, Reich R, Levi-Schaffer F, Berkman N (2006) The CC chemokine eotaxin/CCL11 has a selective profibrogenic effect on human lung fibroblasts. $\mathrm{J}$ Allergy Clin Immunol 117(1):103-110. https://doi.org/10.1016/j. jaci.2005.08.057

184. Kohan M, Puxeddu I, Reich R, Levi-Schaffer F, Berkman N (2010) Eotaxin-2/CCL24 and eotaxin-3/CCL26 exert differential profibrogenic effects on human lung fibroblasts. Ann Allergy Asthma Immunol 104(1):66-72. https://doi.org/10.1016/j. anai.2009.11.003

185. Kohan M, Breuer R, Berkman N (2009) Osteopontin induces airway remodeling and lung fibroblast activation in a murine model of asthma. Am J Respir Cell Mol Biol 41(3):290-296. https://doi.org/10.1165/rcmb.2008-0307OC

186. Delimpoura V, Bakakos P, Tseliou E, Bessa V, Hillas G, Simoes DC, Papiris S, Loukides S (2010) Increased levels of osteopontin in sputum supernatant in severe refractory asthma. Thorax 65(9):782-786. https://doi.org/10.1136/thx.2010.138552

187. Sidhu SS, Yuan S, Innes AL, Kerr S, Woodruff PG, Hou L, Muller SJ, Fahy JV (2010) Roles of epithelial cell-derived periostin in TGF-beta activation, collagen production, and collagen gel elasticity in asthma. Proc Natl Acad Sci USA 107(32):14170 14175. https://doi.org/10.1073/pnas.1009426107

188. Li W, Gao P, Zhi Y, Xu W, Wu Y, Yin J, Zhang J (2015) Periostin: its role in asthma and its potential as a diagnostic or therapeutic target. Respir Res 16:57. https://doi.org/10.1186/s1293 1-015-0218-2

189. O'Dwyer DN, Moore BB (2017) The role of periostin in lung fibrosis and airway remodelling. Cell Mol Life Sci 74(23):43054314. https://doi.org/10.1007/s00018-017-2649-z

190. Izuhara K, Ohta S, Ono J (2016) Using periostin as a biomarker in the treatment of asthma. Allergy Asthma Immunol Res 8(6):491-498. https://doi.org/10.4168/aair.2016.8.6.491

191. Izuhara K, Nunomura S, Nanri Y, Ogawa M, Ono J, Mitamura Y, Yoshihara T (2017) Periostin in inflammation and allergy. Cell Mol Life Sci 74(23):4293-4303. https://doi.org/10.1007/s0001 8-017-2648-0

192. Jia G, Erickson RW, Choy DF, Mosesova S, Wu LC, Solberg OD, Shikotra A et al (2012) Periostin is a systemic biomarker of eosinophilic airway inflammation in asthmatic patients. $\mathbf{J}$ Allergy Clin Immunol 130(3):647-654. https://doi.org/10.1016/j. jaci.2012.06.025

193. Matsusaka M, Kabata H, Fukunaga K, Suzuki Y, Masaki K, Mochimaru T, Sakamaki F, Oyamada Y, Inoue T, Oguma T, Sayama K, Koh H, Nakamura M, Umeda A, Ono J, Ohta S, Izuhara K, Asano K, Betsuyaku T (2014) Phenotype of asthma related with high serum periostin levels. Allergol Int 64(2):175-180. https://doi.org/10.1016/j.alit.2014.07.003

194. Emprm V, Rajanandh MG, Nageswari AD (2016) Periostin-a novel systemic biomarker for eosinophilic airway inflammation: a case control study. J Clin Diagn Res 10(2):OC01-OC04. https ://doi.org/10.7860/jcdr/2016/14553.7166

195. Górska K, Maskey-Warzęchowska M, Nejman-Gryz P, Korczyński P, Prochorec-Sobieszek M, Krenke R (2016) Comparative study of periostin expression in different respiratory 
samples in patients with asthma and chronic obstructive pulmonary disease. Pol Arch Med Wewn 126(3):124-137. https://doi. org/10.20452/pamw.3299

196. James A, Janson C, Malinovschi A, Holweg C, Alving K, Ono J, Ohta S, Ek A, Middelveld R, Dahlén B, Forsberg B, Izuhara K, Dahlén SE (2017) Serum periostin relates to type-2 inflammation and lung function in asthma: data from the large populationbased cohort Swedish GA(2)LEN. Allergy 72(11):1753-1760. https://doi.org/10.1111/all.13181

197. Kanaoka M, Yamaguchi Y, Komitsu N, Feghali-Bostwick CA, Ogawa M, Arima K, Izuhara K, Aihara M (2018) Pro-fibrotic phenotype of human skin fibroblasts induced by periostin via modulating TGF- $\beta$ signaling. J Dermatol Sci 90(2):199-208. https://doi.org/10.1016/j.jdermsci.2018.02.001

198. Ashley SL, Wilke CA, Kim KK, Moore BB (2017) Periostin regulates fibrocyte function to promote myofibroblast differentiation and lung fibrosis. Mucosal Immunol 10(2):341-351. https://doi.org/10.1038/mi.2016.61

199. Liu T, Dhanasekaran SM, Jin H, Hu B, Tomlins SA, Chinnaiyan AM, Phan SH (2004) FIZZ1 stimulation of myofibroblast differentiation. Am J Pathol 164(4):1315-1326. https://doi. org/10.1016/S0002-9440(10)63218-X

200. Dong L, Wang SJ, Camoretti-Mercado B, Li HJ, Chen M, Bi WX (2008) FIZZ1 plays a crucial role in early stage airway remodeling of OVA-induced asthma. J Asthma 45(8):648-653. https://doi.org/10.1080/02770900802126941

201. Liu T, Yu H, Ullenbruch M, Jin H, Ito T, Wu Z, Liu J, Phan SH (2014) The in vivo fibrotic role of FIZZ1 in pulmonary fibrosis. PLoS One 9(2):e88362. https://doi.org/10.1371/journ al.pone. 0088362

202. Asakura T, Ishii Y, Chibana K, Fukuda T (2004) Leukotriene D4 stimulates collagen production from myofibroblasts transformed by TGF-beta. J Allergy Clin Immunol 114(2):310-315. https://doi.org/10.1016/j.jaci.2004.04.037

203. Eap R, Jacques E, Semlali A, Plante S, Chakir J (2012) Cysteinyl leukotrienes regulate TGF- $\beta(1)$ and collagen production by bronchial fibroblasts obtained from asthmatic subjects. Prostagland Leukot Essent Fatty Acids 86(3):127-133. https:// doi.org/10.1016/j.plefa.2011.11.001

204. Sabatini F, Luppi F, Petecchia L, Stefano AD, Longo AM, Eva A, Vanni C, Hiemstra PS, Sterk PJ, Sorbello V, Fabbri LM, Rossi GA, Ricciardolo FL (2013) Bradykinin-induced asthmatic fibroblast/myofibroblast activities via bradykinin B2 receptor and different MAPK pathways. Eur J Pharmacol 710(1-3):100-109. https://doi.org/10.1016/j.ejpha r.2013.03.048

205. Dubé J, Chakir J, Dubé C, Grimard Y, Laviolette M, Boulet LP (2000) Synergistic action of endothelin (ET)-1 on the activation of bronchial fibroblast isolated from normal and asthmatic subjects. Int J Exp Pathol 81(6):429-437. https://doi.org/10.1 046/j.1365-2613.2000.00173.x

206. Gallelli L, Pelaia G, D'Agostino B, Cuda G, Vatrella A, Fratto D, Gioffrè V, Galderisi U, De Nardo M, Mastruzzo C, Salinaro ET, Maniscalco M, Sofia M, Crimi N, Rossi F, Caputi M, Costanzo FS, Maselli R, Marsico SA, Vancheri C (2005) Endothelin-1 induces proliferation of human lung fibroblasts and IL-11 secretion through an ET(A) receptor-dependent activation of MAP kinases. J Cell Biochem 96(4):858-868. https ://doi.org/10.1002/jcb.20608

207. Balestrini JL, Chaudhry S, Sarrazy V, Koehler A, Hinz B (2012) The mechanical memory of lung myofibroblasts. Integr Biol (Camb) 4(4):410-421. https://doi.org/10.1039/c2ib0 0149g

208. Arora PD, Narani N, McCulloch CA (1999) The compliance of collagen gels regulates transforming growth factor-beta induction of alpha-smooth muscle actin in fibroblasts. Am J Pathol
154(3):871-882. https://doi.org/10.1016/S0002-9440(10)65334 $-5$

209. Hinz B, Celetta G, Tomasek JJ, Gabbiani G, Chaponnier C (2001) Alpha-smooth muscle actin expression upregulates fibroblast contractile activity. Mol Biol Cell 12(9):2730-2741. https ://doi.org/10.1091/mbc.12.9.2730

210. Wang J, Chen H, Seth A, McCulloch CA (2003) Mechanical force regulation of myofibroblast differentiation in cardiac fibroblasts. Am J Physiol Heart Circ Physiol 285(5):H1871-H1881. https://doi.org/10.1152/ajpheart.00387.2003

211. Choe MM, Sporn PH, Swartz MA (2006) Extracellular matrix remodeling by dynamic strain in a three-dimensional tissueengineered human airway wall model. Am J Respir Cell Mol Biol 35(3):306-313. https://doi.org/10.1165/rcmb.2005-0443OC

212. Hinz B (2012) Mechanical aspects of lung fibrosis: a spotlight on the myofibroblast. Proc Am Thorac Soc 9(3):137-147. https ://doi.org/10.1039/c2ib00149g

213. Dolhnikoff M, Mauad T, Ludwig MS (1999) Extracellular matrix and oscillatory mechanics of rat lung parenchyma in bleomycininduced fibrosis. Am J Respir Crit Care Med 160(5):1750-1757. https://doi.org/10.1164/ajrccm.160.5.9812040

214. Ebihara T, Venkatesan N, Tanaka R, Ludwig MS (2000) Changes in extracellular matrix and tissue viscoelasticity in bleomycininduced lung fibrosis: temporal aspects. Am J Respir Crit Care Med 162(4):1569-1576. https://doi.org/10.1164/ajrcc m.162.4.9912011

215. Liu F, Tschumperlin DJ (2011) Micro-mechanical characterization of lung tissue using atomic force microscopy. J Vis Exp 54:2911. https://doi.org/10.3791/2911

216. Soucy PA, Werbin J, Heinz W, Hoh JH, Romer LH (2011) Microelastic properties of lung cell-derived extracellular matrix. Acta Biomater 7:96-105. https://doi.org/10.1016/j.actbio.2010.07.021

217. Shi Y, Dong Y, Duan Y, Jiang X, Chen C, Deng L (2013) Substrate stiffness influences TGF- $\beta 1$-induced differentiation of bronchial fibroblasts into myofibroblasts in airway remodeling. Mol Med Rep 7(2):419-424. https://doi.org/10.3892/ mmr.2012.1213

218. Manuyakorn W (2014) Airway remodelling in asthma: role for mechanical forces. Asia Pac Allergy 4(1):19-24. https://doi. org/10.5415/apallergy.2014.4.1.19

219. Manuyakorn W, Smart DE, Noto A, Bucchieri F, Haitchi HM, Holgate ST, Howarth PH, Davies DE (2016) mechanical strain causes adaptive change in bronchial fibroblasts enhancing profibrotic and inflammatory responses. PLoS One 11(4):e0153926. https://doi.org/10.1371/journal.pone.0153926

220. Breen EC (1985) Mechanical strain increases type I collagen expression in pulmonary fibroblasts in vitro. J Appl Physiol 88(1):203-209. https://doi.org/10.1152/jappl.2000.88.1.203

221. Ludwig MS, Ftouhi-Paquin N, Huang W, Pagé N, Chakir J, Hamid Q (2004) Mechanical strain enhances proteoglycan message in fibroblasts from asthmatic subjects. Clin Exp Allergy 34(6):926-930. https://doi.org/10.1111/j.1365-2222.2004.01980 . $\mathrm{X}$

222. Le Bellego F, Perera H, Plante S, Chakir J, Hamid Q, Ludwig MS (2009) Mechanical strain increases cytokine and chemokine production in bronchial fibroblasts from asthmatic patients. Allergy 64(1):32-39. https://doi.org/10.1111/j.1398-9995.2008.01814.x

223. Michalik M, Pierzchalska M, Włodarczyk A, Wójcik KA, Czyż J, Sanak M, Madeja Z (2011) Transition of asthmatic bronchial fibroblasts to myofibroblasts is inhibited by cell-cell contacts. Respir Med 105(10):1467-1475. https://doi.org/10.1016/j. rmed.2011.04.009

224. Reeves SR, Kolstad T, Lien TY, Herrington-Shaner S, Debley JS (2015) Fibroblast-myofibroblast transition is differentially regulated by bronchial epithelial cells from asthmatic children. Respir Res 16:21. https://doi.org/10.1186/s12931-015-0185-7 
225. Ge Q, Zeng Q, Tjin G, Lau E, Black JL, Oliver BG, Burgess JK (2015) Differential deposition of fibronectin by asthmatic bronchial epithelial cells. Am J Physiol Lung Cell Mol Physiol 309(10):L1093-L1102. https://doi.org/10.1152/ajplung.00019 .2015

226. Kohan M, Muro AF, Bader R, Berkman N (2011) The extra domain A of fibronectin is essential for allergen-induced airway fibrosis and hyperresponsiveness in mice. J Allergy Clin Immunol 127(2):439-446. https://doi.org/10.1016/j.jaci.2010.10.021

227. Rogers NK, Clements D, Dongre A, Harrison TW, Shaw D, Johnson SR (2014) Extra-cellular matrix proteins induce matrix metalloproteinase-1 (MMP-1) activity and increase airway smooth muscle contraction in asthma. PLoS One 9(2):e90565. https:// doi.org/10.1371/journal.pone.0090565

228. Laitinen A, Altraja A, Kämpe M, Linden M, Virtanen I, Laitinen LA (1997) Tenascin is increased in airway basement membrane of asthmatics and decreased by an inhaled steroid. Am J Respir Crit Care Med 156(3 Pt 1):951-958. https://doi.org/10.1164/ajrcc m.156.3.9610084

229. Nakahara H, Gabazza EC, Fujimoto H, Nishii Y, D’AlessandroGabazza CN, Bruno NE, Takagi T, Hayashi T, Maruyama J, Maruyama K, Imanaka-Yoshida K, Suzuki K, Yoshida T, Adachi Y, Taguchi O (2006) Deficiency of tenascin C attenuates allergen-induced bronchial asthma in the mouse. Eur J Immunol 36(12):3334-3345. https://doi.org/10.1002/eji.200636271

230. Lau JY, Oliver BG, Baraket M, Beckett EL, Hansbro NG, Moir LM, Wilton SD, Williams C, Foster PS, Hansbro PM, Black JL, Burgess JK (2010) Fibulin-1 is increased in asthma-a novel mediator of airway remodeling? PLoS One 5(10):e13360. https ://doi.org/10.1371/journal.pone.0013360

231. Giziry DE, Zakaria NH, Kassem AH, Abdellatif MM (2017) The study of fibulin-1 as a novel biomarker in bronchial asthma and its association with disease severity. Egypt J Chest Dis Tuberc 66(3):385-389. https://doi.org/10.1016/j.ejcdt.2016.12.003

232. Klingberg F, Chau G, Walraven M, Boo S, Koehler A, Chow ML, Olsen AL, Im M, Lodyga M, Wells RG, White ES, Hinz B (2018) The fibronectin ED-A domain enhances recruitment of latent TGF- $\beta$-binding protein-1 to the fibroblast matrix. J Cell Sci. https://doi.org/10.1242/jcs.201293

233. Kotaru C, Schoonover KJ, Trudeau JB, Huynh ML, Zhou X, Hu $\mathrm{H}$, Wenzel SE (2006) Regional fibroblast heterogeneity in the lung: implications for remodeling. Am J Respir Crit Care Med 173:1208-1215. https://doi.org/10.1164/rccm.200508-1218OC

234. Paw M, Borek I, Wnuk D, Ryszawy D, Piwowarczyk K, Kmiotek K, Wójcik-Pszczoła KA, Pierzchalska M, Madeja Z, Sanak M, Błyszczuk P, Michalik M, Czyż J (2017) Connexin43 controls the myofibroblastic differentiation of bronchial fibroblasts from asthmatic patients. Am J Respir Cell Mol Biol 57(1):100-110. https://doi.org/10.1165/rcmb.2015-0255OC

235. Gombedza F, Kondeti V, Al-Azzam N, Koppes S, Duah E, Patil P, Hexter M, Phillips D, Thodeti CK, Paruchuri S (2017) Mechanosensitive transient receptor potential vanilloid 4 regulates dermatophagoides farinae-induced airway remodeling via 2 distinct pathways modulating matrix synthesis and degradation. FASEB J 31(4):1556-1570. https://doi.org/10.1096/fj.201601045R

236. Tarzemany R, Jiang G, Jiang JX, Larjava H, Häkkinen L (2017) Connexin 43 hemichannels regulate the expression of wound healing-associated genes in human gingival fibroblasts. Sci Rep 7(1):14157. https://doi.org/10.1038/s41598-017-12672-1

237. Czyż J, Piwowarczyk K, Paw M, Luty M, Wróbel T, Catapano J, Madeja Z, Ryszawy D (2017) Connexin-dependent intercellular stress signaling in tissue homeostasis and tumor development. Acta Biochim Pol 64(3):377-389. https://doi.org/10.18388 /abp.2017_1592

238. Michalik M, Wójcik KA, Jakieła B, Szpak K, Pierzchalska M, Sanak M, Madeja Z, Czyż J (2012) Lithium attenuates
TGF- $\beta 1$-induced fibroblasts to myofibroblasts transition in bronchial fibroblasts derived from asthmatic patients. J Allergy (Cairo) 2012:206109. https://doi.org/10.1155/2012/206109

239. James AJ, Penrose JF, Cazaly AM, Holgate ST, Sampson AP (2006) Human bronchial fibroblasts express the 5-lipoxygenase pathway. Respir Res 7:102. https://doi. org/10.1186/1465-9921-7-102

240. Pierzchalska M, Szabó Z, Sanak M, Soja J, Szczeklik A (2003) Deficient prostaglandin E2 production by bronchial fibroblasts of asthmatic patients, with special reference to aspirin-induced asthma. J Allergy Clin Immunol 111(5):1041-1048. https://doi. org/10.1067/mai.2003.1491

241. Westergren-Thorsson G, Chakir J, Lafrenière-Allard MJ, Boulet LP, Tremblay GM (2002) Correlation between airway responsiveness and proteoglycan production by bronchial fibroblasts from normal and asthmatic subjects. Int J Biochem Cell Biol 34(10):1256-1267. https://doi.org/10.1016/S1357 $-2725(02) 00058-4$

242. Liang J, Jiang D, Jung Y, Xie T, Ingram J, Church T, Degan S, Leonard M, Kraft M, Noble PW (2011) Role of hyaluronan and hyaluronan-binding proteins in human asthma. J Allergy Clin Immunol 128(2):403-411. https://doi.org/10.1016/j. jaci.2011.04.006

243. Schaafsma D, McNeill KD, Mutawe MM, Ghavami S, Unruh H, Jacques E, Laviolette M, Chakir J, Halayko AJ (2011) Simvastatin inhibits TGF- $\beta 1$-induced fibronectin in human airway fibroblasts. Respir Res 12:113. https://doi.org/10.1186/1465-9921-12-113

244. Nakamura Y, Esnault S, Maeda T, Kelly EA, Malter JS, Jarjour NN (2004) Ets-1 regulates TNF-alpha-induced matrix metalloproteinase- 9 and tenascin expression in primary bronchial fibroblasts. J Immunol 172(3):1945-1952. https://doi.org/10.4049/ jimmunol.172.3.1945

245. Laliberté R, Rouabhia M, Bossé M, Chakir J (2001) Decreased capacity of asthmatic bronchial fibroblasts to degrade collagen. Matrix Biol 19(8):743-753. https://doi.org/10.1016/S0945 $-053 X(00) 00120-7$

246. Bergeron C, Pagé N, Joubert P, Barbeau B, Hamid Q, Chakir J (2003) Regulation of procollagen I ( $\alpha 1)$ by interleukin-4 in human bronchial fibroblasts: a possible role in airway remodelling in asthma. Clin Exp Allergy 33(10):1389-1397. https://doi. org/10.1046/j.1365-2222.2003.01785.x

247. Pelaia G, Gallelli L, D’Agostino B, Vatrella A, Cuda G, Fratto D, Renda T, Galderisi U, Piegari E, Crimi N, Rossi F, Caputi M, Costanzo FS, Vancheri C, Maselli R, Marsico SA (2007) Effects of TGF-beta and glucocorticoids on map kinase phosphorylation, IL-6/IL-11 secretion and cell proliferation in primary cultures of human lung fibroblasts. J Cell Physiol 210(2):489-497. https:// doi.org/10.1002/jcp.20884

248. McMillan SJ, Xanthou G, Lloyd CM (2005) Manipulation of allergen-induced airway remodeling by treatment with anti-TGFbeta antibody: effect on the Smad signaling pathway. J Immunol 174(9):5774-5780. https://doi.org/10.4049/jimmunol.174.9.5774

249. Rama A, Matsushita T, Charolidi N, Rothery S, Dupont E, Severs NJ (2006) Up-regulation of connexin 43 correlates with increased synthetic activity and enhanced contractile differentiation in TGF-beta-treated human aortic smooth muscle cells. Eur J Cell Biol 85:375-386. https://doi.org/10.1016/j.ejcb.2005.11.007

250. Dai P, Nakagami T, Tanaka H, Hitomi T, Takamatsu T (2007) Cx43 mediates TGF-beta signaling through competitive Smads binding to microtubules. Mol Biol Cell 18(6):2264-2273. https ://doi.org/10.1091/mbc.E06-12-1064

251. Asazuma-Nakamura Y, Dai P, Harada Y, Jiang Y, Hamaoka K, Takamatsu T (2009) Cx43 contributes to TGF-beta signaling to regulate differentiation of cardiac fibroblasts into myofibroblasts. Exp Cell Res 315(7):1190-1199. https://doi.org/10.1016/j.yexcr .2008 .12 .021 
252. Harvey KA, Paranavitana CN, Zaloga GP, Siddiqui RA (2007) Diverse signaling pathways regulate fibroblast differentiation and transformation through Rho kinase activation. J Cell Physiol 211(2):353-363. https://doi.org/10.1002/jcp.20939

253. Baarsma HA, Engelbertink LH, van Hees LJ, Menzen MH, Meurs H, Timens W, Postma DS, Kerstjens HA, Gosens R (2013) Glycogen synthase kinase-3 (GSK-3) regulates TGF- $\beta_{1}$ induced differentiation of pulmonary fibroblasts. $\mathrm{Br} \mathrm{J}$ Pharmacol 169(3):590-603. https://doi.org/10.1111/bph.12098

254. Wójcik KA, Skoda M, Koczurkiewicz P, Sanak M, Czyż J, Michalik M (2013) Apigenin inhibits TGF- $\beta 1$ induced fibroblastto-myofibroblast transition in human lung fibroblast populations. Pharmacol Rep 65(1):164-172. https://doi.org/10.1016/S1734 -1140(13)70974-5

255. Michalik M, Soczek E, Kosińska M, Rak M, Wójcik KA, Lasota S, Pierzchalska M, Czyż J, Madeja Z (2013) Lovastatin-induced decrease of intracellular cholesterol level attenuates fibroblastto-myofibroblast transition in bronchial fibroblasts derived from asthmatic patients. Eur J Pharmacol 704(1-3):23-32. https://doi. org/10.1016/j.ejphar.2013.02.023

256. Wójcik-Pszczoła K, Hińcza K, Wnuk D, Kądziołka D, Koczurkiewicz P, Sanak M, Madeja Z, Pękala E, Michalik M (2016) Pentoxifylline and its active metabolite lisofylline attenuate transforming growth factor $\beta 1$-induced asthmatic bronchial fibroblast-to-myofibroblast transition. Acta Biochim Pol 63(3):437-442. https://doi.org/10.18388/abp.2016_1357

257. Pechkovsky DV, Hackett TL, An SS, Shaheen F, Murray LA, Knight DA (2010) Human lung parenchyma but not proximal bronchi produces fibroblasts with enhanced TGF- $\beta$ signaling and alpha-SMA expression. Am J Respir Cell Mol Biol 43(6):641651. https://doi.org/10.1165/rcmb.2009-0318oc

258. Rodemann HP, Rennekampff HO (2011) Functional Diversity of Fibroblasts. In: Mueller MM, Fusenig NE (eds) Tumor-Associated Fibroblasts and their Matrix. Springer, Netherlands, pp 23-36. https://doi.org/10.1007/978-94-007-0659-0_2

259. Ho SM (2010) Environmental epigenetic of asthma - an update. J Allergy Clin Immunol 126(3):453-465. https://doi.org/10.1016/j. jaci.2010.07.030

260. Blumenthal MN (2012) Genetic, epinetic, and environmental factors in asthma and allergy. Ann Allergy Asthma Immunol 108(2):69-73. https://doi.org/10.1016/j.anai.2011.12.003

261. Lee JU, Kim JD, Park CS (2015) Gene-environment interactions in asthma: genetic and epigenetic effects. Yonsei Med J 56(4):877-886. https://doi.org/10.3349/ymj.2015.56.4.877

262. Chogtu B, Bhattacharjee D, Magazine R (2016) Epigenetics: the new frontier in the landscape of asthma. Scientifica (Cairo) 2016:4638949. https://doi.org/10.1155/2016/4638949 